\title{
POLÍTICAS PÚBLICAS VOLTADAS PARA A POPULAÇÃO IDOSA: UMA AVALIAÇÃO DOS IDOSOS QUE FREQUENTAM OS CRAS DE ITUIUTABA (MG)
}

\section{PUBLIC POLICIES ON THE ELDERLY POPULATION: AN APPRECIATION OF THE ELDERLY OF THE ELDERLY WHO ATTEND THE CRAS DE ITUIUTABA (MG)}

\author{
Geisa Candida da Silva Gonçalves \\ Mestre em Geografia pela Universidade Federal de Uberlândia (UFU) \\ geisa.goncalves@ufu.br \\ Gerusa Gonçalves Moura \\ Doutora em Geografia pela Universidade Federal de Uberlândia (UFU) \\ gerusaufu@gmail.com
}

\begin{abstract}
RESUMO
A população idosa mundial cresceu substancialmente e, para atender às novas demandas, o Estado apresenta políticas públicas voltadas para os idosos que supram suas necessidades, garantindo-Ihes os serviços essenciais. O objetivo desse estudo é perceber como os idosos que frequentam os seis Centros de Referência de Assistência Social (CRAS) instalados na cidade de Ituiutaba (MG), avaliam as políticas públicas voltadas para a população idosa, verificando o entendimento dos mesmos a respeito de tais políticas e indicando ações que contemplem as necessidades desta população. Para isso, foram entrevistados os idosos que participam das atividades e projetos realizados CRAS de Ituiutaba. Os resultados indicam que os entrevistados reconhecem a importância do CRAS, o excelente atendimento que recebem e a necessidade de melhoria dos espaços físicos. Há uma grande dificuldade dos idosos em entender as políticas públicas voltadas para eles, bem como quais direitos são assegurados por elas. Outro resultado interessante é a prioridade que eles atribuem ao transporte público e ao atendimento público da saúde, evidenciando que estes são os "direitos" considerados mais importantes. Fica evidente a necessidade de mais pesquisas e ações que contribuam para a valorização dos idosos, bem como seu engajamento na sociedade e, sobretudo, a garantia de um envelhecimento com qualidade, segurança e dignidade.
\end{abstract}

Palavras-Chave: Políticas Públicas. População Idosa. Avaliação. Ituiutaba (MG).

\begin{abstract}
The world's elderly population has grown substantially and, to attend the new demands, the State presents public policies aimed at the elderly that attend their needs, guaranteeing them essential services. The objective of this study is to understand how the elderly, who attend the six Centers of Reference and Social Assistance (CRAS) installed in the Ituiutaba City, appreciate the public policies aimed to the elderly population, verifying their understanding of such policies and indicating actions that that contemplate the needs of this population. For this, the elderly who participated in the activities and projects performed by CRAS in Ituiutaba were interviewed. The results indicate that the interviewees recognize the importance of CRAS, the excellent service they receive and the need to improve physical spaces. There is a great difficulty for the elderly in understanding public policies aimed at them, as well as what rights are guaranteed by them. Another interesting result is the priority they attach to public transport and public health care, making it clear that these are the "rights" considered to be the most important. It is evident the need for more research and actions that contribute to the valorization of the elderly, as well as their engagement in society and, above all, the guarantee of aging with quality, safety and dignity.
\end{abstract}

Keywords: Public Policies. Elderly Population. Appreciation. Ituiutaba (MG). 


\section{INTRODUÇÃO}

O crescimento da população idosa brasileira ocorreu de forma rápida e acentuada, gerando grandes desafios sociais e provocando transformações familiares, sociais, urbanas e industriais. Para definir uma pessoa como idosa, a Organização Mundial da Saúde (OMS) utiliza, como critério, a idade cronológica, ou seja, a idade real de um ser humano, como critério. Nos países desenvolvidos, o termo é utilizado para a pessoa com sessenta e cinco anos ou mais, conforme a World Health Organization (2005), enquanto nos países em desenvolvimento, são considerados como idosos as pessoas com sessenta anos ou mais. No Brasil, conforme o Estatuto do Idoso e a Política Nacional do Idoso - PNI (1994), considera-se idosa a pessoa com idade superior a sessenta anos.

As estimativas sugerem que, em 2050, a população idosa mundial será composta por 1,9 bilhão de pessoas, conforme Cruvinel (2009).E, conforme dados apontados por Brasil (2015), a taxa de envelhecimento de sua população brasileira não está diferente da média mundial, ou seja, aumentou $4,52 \%$ no período de 1991 a 2010 , sendo que $14,5 \%$ da estrutura etária do município já era composta por idosos. Minas Gerais, por sua vez, segundo o Instituto Brasileiro de Geografia e Estatística - IBGE (2018), até o ano de 2060será o Estado brasileiro com o maior número de idosos, sendo que, quase um em cada três mineiros terá 65 anos ou mais. Ainda segundo a previsão do IBGE (2018), em 2060, a cada dez mineiros, sete serão dependentes da população entre 15 e 64 anos.

Essa estrutura etária populacional provocou uma evolução do conceito legal de idoso, bem como despertou a responsabilidade do Estado e da sociedade para cuidar desse grupo populacional, ou seja, da população idosa. Assim, para atender as demandas públicas e sociais dos idosos e da população como um todo, os Estados criaram as políticas públicas, ou seja, ferramentas utilizadas para garantir direitos e assegurar qualidade de vida à população, em especial à população idosa.

Nesse sentido, o objetivo deste trabalho é compreender como os idosos percebem as políticas públicas voltadas para a população idosa, tendo como estudo de caso o município de Ituiutaba/MG. Para a realização desta pesquisa, a metodologia baseou-se, inicialmente, numa revisão de literatura, dentre os principais autores que abordam o tema, para a compreensão dos conceitos envolvidos. Também foram consultadas as leis municipais; informações do Ministério do Desenvolvimento Social (2015) sobre os Centros de Referências de Assistência Social (CRAS); os sites da Organização Mundial da Saúde (OMS), Instituto Brasileiro de Geografia e Estatística (IBGE) e da Prefeitura Municipal de Ituiutaba (PMI).

Estabeleceu-se como amostra desse estudo os idosos que participam de atividades e projetos realizados nos seis CRAS de Ituiutaba (MG)Segundo dados levantados junto à Secretaria Municipal de Desenvolvimento Social(SEDS), são atendidos uma média de 250 (duzentos e cinquenta) idosos em todos os CRAS de Ituiutaba, os quais se constituíram no universo amostral dessa pesquisa. Para elaborar a amostra da pesquisa, utilizou-se a tabela de Krejcie e Morgan e apresentada por Gerardi e Silva $(1981$, p. 20) e conforme a referida tabela, tal amostra foi composta por 153 idosos. E, para o tratamento dos dados foi utilizada a técnica de análise de conteúdo baseada em Bardin (2011), a qual possibilita analisar as respostas obtidas e realizar comparações sistemáticas, sendo possível apresentar os resultados através de indicadores quantitativos e qualitativos.

Dessa forma, esse artigo será estruturado em três etapas, sendo que na primeira será abordado algumas considerações importantes sobre o conceito de envelhecer e de políticas públicas. No segundo momento será apresentado as políticas públicas direcionadas para a população idosa de Ituiutaba/MG e, na terceira e última etapa, o resultado da pesquisa propriamente dita, onde será demonstrado o entendimento dos idosos entrevistados sobre as políticas públicas direcionadas especificamente para a população idosa.

\section{SOBRE ENVELHECER E A LEGISLAÇÃO: algumas considerações importantes}

O envelhecimento populacional vem provocando mudanças demográficas em todo o mundo. Porém, conforme Moura e Souza (2012), enquanto nos países desenvolvidos demorou mais de cem anos, nos países em desenvolvimento o processo de envelhecimento vem ocorrendo rapidamente, modificando a pirâmide populacional. Trata-se de um processo natural e irreversível, percebido de diferentes formas conforme as experiências de cada um.

$\begin{array}{lllll}\text { Caminhos de Geografia } & \text { Uberlândia-MG } & \text { v. 21, n. } 76 & \text { Ago/2020 } & \text { p. 208-230 Página } 209\end{array}$


A população brasileira vem passando por esse processo de transição demográfica desde 1950 , conforme explicado por Berquó e Baeninger (2000). Tais autoras também citam o desaceleramento do ritmo de crescimento populacional ocorrido no Brasil a partir de 1960, alterando a estrutura etária da sua população em função do acentuado declínio da fecundidade, contribuindo para que a população idosa tenha seu peso relativo aumentado no total da população.

Conforme Moura e Souza (2012), dados do Instituto Brasileiro de Geografia e Estatística (IBGE) apontam o Brasil como um dos países latinos cuja população idosa teve um grande aumento em relação ao total da população, aumentando a demanda de políticas públicas e pressionando a distribuição de recursos, gerando maiores gastos do Estado com a saúde, previdência, aposentadoria, dentre outros.

Diante do envelhecimento populacional, vários debates se iniciaram sobre os direitos da população idosa, tornando imprescindível a formulação de políticas públicas a serem efetivadas visando atender as necessidades e as demandas desse grupo populacional. Embora haja muitas políticas públicas voltadas para a população idosa, sua implementação é dificultada por fatores que vão desde a precariedade na captação de recursos até a fragilidade do sistema de informação que analisa as condições de vida e de saúde, além da falta de capacitação dos recursos humanos envolvidos no processo. Portanto, essa dificuldade não se deve à falta de legislações, uma vez que há várias respaldando os direitos dos idosos, como poderá ser visto a seguir.

O primeiro documento que registra os direitos dos idosos é justamente, a Declaração Universal dos Direitos Humanos, proclamada e adotada em 10 de dezembro de 1948 pela Assembleia Geral das Nações Unidas. No Brasil, a primeira lei voltada para a população idosa foi promulgada em 28 de setembro de 1885. Porém, segundo Fonseca (2009), tratava-se de uma lei específica para os negros escravizados denominada Lei dos Sexagenários ou Lei Saraiva-Cotegipe, a qual garantia a liberdade aos escravos com 60 anos de idade ou mais.

Somente no início da década de 1970, conforme Silva e Souza (2010), passou-se a debater sobre os direitos dos idosos, mediante a constatação do aumento dessa parcela da população. Tal verificação se deu através de uma pesquisa realizada pelo Ministério da Previdência Social, levando-se a compreender que a questão requeria medidas de políticas sociais mais efetivas.

O Decreto $n^{\circ} 72.771$ de 06 de setembro de 1973 definiu as condições para usufruir a pensão por velhice, determinando65 anos para homens e 60 anos para mulheres. Esse decreto aprovou o regulamento da Lei ${ }^{\circ} 3.807 / 1960$ que dispunha sobre a Lei Orgânica da Previdência Social, revogado em 06 de maio de 1999 pelo Decreto n 3.048, aprovando o Regulamento da Previdência Social.

Em 1988, a Constituição Federal marcou as políticas sociais ao apresentar um conceito de proteção social mais abrangente, bem como várias regulamentações que garantiam direitos fundamentais ao idoso. Silva e Souza (2010, p. 89) apontam que:

Nesse período, a questão do envelhecimento já estava sendo bastante discutida, sendo reconhecida como questão social e política relevante, exigindo respostas para esse segmento. E nesse contexto, os idosos encontram espaço adequado para suas reivindicações, fortalecendo o movimento dos aposentados e pensionistas, sendo este o movimento mais expressivo já realizado pelas pessoas idosas no país.

Em seu artigo 196, a Constituição Federal reconhece a saúde como um direito de todos e dever do Estado, garantido através de políticas sociais e econômicas que visem reduzir o risco de doença e outros agravos, além do acesso universal e igualitário às ações e serviços para sua promoção, proteção e recuperação. Porém, no caso do idoso, além disso, é necessária uma interação entre a saúde física e mental, bem como a independência financeira, a capacidade funcional e o suporte social, conforme Fernandes e Soares (2012).A Constituição Federal aborda os direitos dos idosos de forma específica, garantindo um salário mínimo para a sua subsistência, além do cuidado familiar e social:

Art. 203. A assistência social será prestada a quem dela necessitar, independentemente de contribuição à seguridade social, e tem por objetivos:

I - a proteção à família, à maternidade, à infância, à adolescência e à velhice;

V - a garantia de um salário mínimo de benefício mensal à pessoa portadora de deficiência e ao idoso que comprovem não possuir meios de prover à própria manutenção ou de tê-la provida por sua família, conforme dispuser a lei. 
Art. 229. Os pais têm o dever de assistir, criar e educar os filhos menores, e os filhos maiores têm o dever de ajudar e amparar os pais na velhice, carência ou enfermidade. (BRASIL, 1988, s./p.).

Em 7 de dezembro de 1993 foi promulgada a Lei ${ }^{\circ} 8.742$, como política pública de seguridade social, com a responsabilidade de proteger as populações socialmente vulneráveis. Segundo Brasil (1993), a Lei Orgânica da Assistência Social (LOAS) inclui programas e projetos voltados para os idosos que garantem um mínimo de dignidade e respeito aos mesmos, além de expressar a sua proteção e inclusão social.

Entretanto, somente em 1994 instituiu-se uma política nacional voltada para o idoso, ou seja, a Política Nacional do Idoso (PNI), criada pela Constituição Federal de 1988, assegurando e consolidando direitos sociais, além de amparo legal aos idosos. E, com a aprovação da PNI foi cunhado também o Conselho Nacional do Idoso. A PNI criou condições para a integração, autonomia e efetiva participação do idoso na sociedade, sendo norteada por cinco princípios:

I - a família, a sociedade e o estado têm o dever de assegurar ao idoso todos os direitos da cidadania, garantindo sua participação na comunidade, defendendo sua dignidade, bem-estar e o direito à vida;

II - o processo de envelhecimento diz respeito à sociedade em geral, devendo ser objeto de conhecimento e informação para todos:

III - o idoso não deve sofrer discriminação de qualquer natureza;

IV - o idoso deve ser o principal agente e o destinatário das transformações a serem efetivadas através desta política;

$\mathrm{V}$ - as diferenças econômicas, sociais, regionais e, particularmente, as contradições entre o meio rural e o urbano do Brasil deverão ser observadas pelos poderes públicos e pela sociedade em geral, na aplicação desta lei. (BRASIL, 1994, s./p.).

A Política Nacional da Saúde do Idoso, implantada em 10 de dezembro de 1999, através da Portaria $n^{\circ}$ 1.395 do Ministério da Saúde (MS), estabeleceu as principais diretrizes dos programas, planos, projetos e atividades do setor de saúde na atenção ao idoso, visando garantir sua permanência no seu meio e na sociedade, desenvolvendo suas atividades com independência. Porém, em 19 de outubro de 2006, a mesma foi revogada pela Portaria $n^{\circ} 2.528$ do Ministério da Saúde, aprovando a Política Nacional de Saúde da Pessoa Idosa (PNSPI) e discutindo a inclusão da condição funcional na formulação das políticas públicas para a saúde dos idosos.

Também é importante citar a Lei no 11.433 , de 28 de dezembro de 2006 , que instituiu o dia $1^{\circ}$ de outubro de cada ano como sendo o Dia Nacional do Idoso. Tal legislação torna os órgãos públicos que coordenam e implementam a Política Nacional do Idoso responsáveis pela promoção, realização e divulgação de eventos que valorizem os idosos na sociedade (BRASIL, 2006).

Criado em $1^{\circ}$ de outubro de 2003 , através da Lei $n^{\circ} 10.741$, com o objetivo de regulamentar os direitos garantidos aos cidadãos a partir de 60 anos e normatizar os princípios preconizados pela $\mathrm{PNI}$,o Estatuto do Idoso garante direitos, autonomia e participação social, tratando sobre as medidas de proteção ao idoso e constituindo-se em um instrumento de direito próprio e de cidadania (BRASIL, 2003). Trata-se da lei mais importante de proteção aos direitos do idoso, priorizando tanto as demandas como as normas de proteção, além de inserir novos direitos e mecanismos de fiscalização. $O$ seu artigo $2^{\circ}$ reafirma a igualdade de direitos dos idosos com os demais membros da população:

O idoso goza de todos os direitos fundamentais inerentes à pessoa humana, sem prejuízo da proteção integral de que trata esta Lei, assegurando-se-lhe, por lei ou por outros meios, todas as oportunidades e facilidades, para preservação de sua saúde física e mental e seu aperfeiçoamento moral, intelectual, espiritual e social, em condições de liberdade e dignidade. (BRASIL, 2003, s./p.).

A saúde, a justiça, a cultura, o transporte, os benefícios e a educação dos idosos estão dentre os temas abordados no Estatuto do Idoso. Em seu artigo $3^{\circ}$, ele trata das obrigações da família, da comunidade, da sociedade e do Estado, para com a população idosa, assegurando seus direitos:

É obrigação da família, da comunidade, da sociedade e do Poder Público assegurar ao idoso, com absoluta prioridade, a efetivação do direito à vida, à saúde, à alimentação, à educação, à cultura, ao esporte, ao lazer, ao trabalho, à cidadania, à

$\begin{array}{lllll}\text { Caminhos de Geografia } & \text { Uberlândia-MG } & \text { v. 21, n. 76 } & \text { Ago/2020 } & \text { p. 208-230 Página } 211\end{array}$


liberdade, à dignidade, ao respeito e à convivência familiar e comunitária. (BRASIL, 2003, s./p.).

Os artigos $8^{\circ}$ e $9^{\circ}$ abordam tanto o direito de envelhecer e as obrigações do Estado quanto à implementação de políticas públicas de proteção da vida e da saúde do idoso. Já o artigo $10^{\circ}$ Ihes assegura os direitos constitucionais: liberdade, respeito, dignidade, ressaltando a sua inviolabilidade física, psíquica e moral, enquanto o direito ao trabalho é apontado nos artigos $26^{\circ}, 27^{\circ}$ e $28^{\circ}$. Ainda no que tange à subsistência do idoso, os artigos $29^{\circ}$ a $32^{\circ}$ tratam da previdência social e dos benefícios de aposentadoria e pensão, enquanto os artigos $33^{\circ}$ a $36^{\circ}$ abordam a assistência social mediante os princípios e diretrizes previstos na LOAS, na PNI, no SUS e demais normas relacionadas.

O Estatuto do Idoso também assegura, em seus artigos $37^{\circ}$ e $38^{\circ}$, o direito à moradia digna, bem como garante, em seus artigos $39^{\circ}$ a $42^{\circ}$, a gratuidade dos transportes coletivos públicos e as vagas preferenciais em estacionamentos, tanto públicos quanto particulares, além da prioridade no embarque e desembarque no sistema de transporte coletivo (BRASIL, 2003).

Nem todos os problemas e demandas da população idosa foram solucionados com a aprovação do Estatuto do Idoso e, embora se tenha avançado quanto às legislações brasileiras voltadas para os cuidados com o idoso, a efetivação e a prática delas continuam sendo insatisfatórias. Com a vigência do Estatuto do Idoso tornou-se pública a presença de idosos em famílias fragilizadas, em situação crítica de vulnerabilidade social, conforme aponta Fernandes e Soares (2012). Além disso, mesmo com todo amparo legal, muitas vezes o cidadão precisa utilizar-se da judicialização para fazer valer seus direitos e para que o Estado cumpra seus deveres.

Considerado um país jovem, o Brasil começa a enfrentar os desafios oriundos do aumento da expectativa de vida da população e a busca dos idosos por viver mais e com qualidade. "Entre 2012 e 2016 , a população idosa cresceu $16 \%$, chegando a 29,6 milhões de pessoas. Já a parcela de crianças com até 9 anos de idade na população caiu de $14,1 \%$ para $12,9 \%$ no período", segundo Pesquisa Nacional por Amostra de Domicílios (PNAD), realizada pelo IBGE (2017, s./p.).Com o envelhecimento da população tornou necessário pensar sua qualidade de vida, bem como formas de mantê-la desempenhando suas atividades e funções com prazer e autonomia. Para isso, cabe ao Estado implementar políticas públicas que promovam uma vida ativa, independente e saudável, além de legislar para garantir os direitos de acolhimento dos idosos.

\section{SOBRE AS POLÍTICAS PÚBLICAS PARA O IDOSO NO MUNICÍPIO DE ITUIUTABA (MG)}

Seguindo a tendência mundial, a aceleração do envelhecimento populacional chegou aos municípios, trazendo vários desafios para a gestão municipal. Assim, conforme Ituiutaba (s./d.), a Prefeitura Municipal de Ituiutaba (PMI), juntamente com a Secretaria Municipal de Desenvolvimento Social (SEDS) e o Centro de Referência Especializado de Assistência Social (CREAS), se viram diante de uma realidade social o que os obrigou a colocar em práticas políticas e ações que pudessem garantir a qualidade de vida e o bem estar da população idosa de Ituiutaba/MG. Diante disso, várias leis foram criadas com esse intuito, como veremos a seguir.

Dentre as primeiras leis que de forma indireta buscaram promover um melhor atendimento à população idosa, está o Código de Posturas do Município de Ituiutaba (MG), criado em 10 de dezembro de 1970, através da Lei $n^{\circ} 1.363$. Neste, apresenta-se, dentre outras coisas, os parâmetros e a obrigação do Poder Público de fiscalizar a estrutura e as dimensões dos passeios da cidade, bem como a não obstrução do trânsito dos pedestres (ITUIUTABA, 1970). Apesar de não ser uma ação direcionada especificamente ao público idoso, são ações que contribuem para melhorar a mobilidade dos mesmos pelas vias públicas, mesmo sem abordar a necessidade das rampas de acesso às calçadas, um importante requisito de acessibilidade que possibilita que o idoso mantenha sua autonomia e independência.

Em 24 de abril de 1997, através da Lei Municipal $n^{\circ} 3.231$, foi criado o Conselho Municipal de Assistência Social de Ituiutaba. Conforme Brasil (1993), a LOAS outorga a este Conselho a função de fiscalizar as entidades e organizações de assistência social, contribuindo na criação de políticas públicas específicas para as populações idosas, inclusive. Na mesma data foi instituído o Fundo Municipal de Assistência Social, através da Lei $n^{\circ} 3.232$. O cuidado com a população idosa aparece especificamente nos incisos I e V, do seu artigo $1^{\circ}$ : 
I - a proteção à família, à maternidade, à infância, à adolescência e à velhice;

$\mathrm{V}$ - ao suprimento de carência alimentar à pessoa portadora de doença grave, deficiência, e ao idoso que comprovem não possuir meios de prover a própria manutenção ou de tê-la provida por sua família. (ITUIUTABA, 1997, s./p.).

Outras leis também beneficiaram a população idosa, como a Lei $n^{\circ} 3.269$ de 17 de dezembro de 1997 que assegurou aos idosos o pagamento de meia entrada para ingresso em eventos artísticos, culturais, esportivos e de lazer, bem como preferência no acesso aos locais dos eventos garantido pelo artigo 23 do Estatuto do Idoso. Já a Lei no 3.606 de 23 de abril de 2003 instituiu o Conselho Municipal do Idoso de Ituiutaba (CMII), com "[...] a finalidade de amparar as pessoas idosas, assegurando a sua participação na sociedade, defender a sua dignidade e bem-estar e garantirIhes o direito à vida", (ITUIUTABA, 2003, s./p.). Essa lei foi alterada pela Lei $n^{\circ} 3.907 / 2007$, posteriormente alterada em 25 de agosto de 2011 pela Lei $n^{\circ} 4.099$, hoje em vigor.

Em 11 de janeiro de 2007, a Lei $n^{\circ} 3.831$ determinou ao Poder Público Municipal que a Administração Pública Direta e Indireta priorize a tramitação dos seus procedimentos administrativos que atendam cidadãos idosos (ITUIUTABA, 2007). Já em 23 de abril de 2015, através da Lei $n^{\circ} 4.351$ da Câmara Municipal de Ituiutaba, foi criado o Fundo Municipal do Idoso, objetivando a captação e aplicação dos recursos voltados às ações destinadas ao atendimento do público idoso, conforme Ituiutaba (2015).

O Plano de Mobilidade Urbana de Ituiutaba, instituído em 06 de julho de 2017 pela Lei $n^{\circ} 4.507$, tem com o objetivo promover a sustentabilidade urbana e melhorar os deslocamentos, tratando também sobre as adequações das calçadas e passeios, bem como sobre a construção de rampas de acesso, condições importantes para a segurança na locomoção e acessibilidade do idoso. A preocupação com os mesmos aparece de forma direta no parágrafo único do artigo 12:

Todos os cruzamentos semaforizados devem possuir temporizador para pedestres com indicação luminosa e sonora. Parágrafo único. No cálculo do tempo para travessia de pedestre deve ser considerado o tempo de deslocamento do idoso e das pessoas com mobilidade reduzida. (ITUIUTABA, 2017, s./p.).

E, posteriormente, nos incisos I, II e III do artigo 34:

Os editais de concessão de operação do sistema de transporte público devem conter no mínimo as seguintes exigências: I - identificação dos assentos de no mínimo $10 \%$ com cores diferenciadas para idosos e gestantes; II - garantir o transporte gratuito ao idoso com mais de 65 anos, ainda que em outros assentos não identificados (que ultrapassem o mínimo de 10\%); III - implantar o cartão do idoso; (ITUIUTABA, 2017, s./p.).

Em 13 de julho de 2018, o Plano Diretor Integrado do Município de Ituiutaba foi revisado pela Lei Complementar $n^{\circ} 153$ abordando as funções sociais da cidade, a mobilidade urbana e a acessibilidade universal e mais uma vez prioriza a população idosa. O capítulo IV aborda as políticas sociais, constando na alínea d do artigo 35:

d) considerar a transversalidade das políticas sociais para a promoção da igualdade de gênero, de raça e de cultura, bem como as políticas específicas para as crianças, jovens, idosos e pessoas com deficiência; (ITUIUTABA, 2018, p. 16).

Neste mesmo Plano Diretor, vários outros artigos atentam-se para o atendimento das necessidades da população idosos, como por exemplo nos incisos VI e VII do artigo supracitado, as medidas e ações necessárias para adequação dos espaços públicos e a promoção da inclusão e acolhimento das pessoas com mobilidade reduzida são descritas. No inciso VI do artigo 50, o Plano Diretor de Ituiutaba aborda a promoção do esporte e do lazer para a população idosa. Já em seu artigo 55, inciso VIII, aborda a prioridade na provisão de habitação para grupos de vulnerabilidade social, dentre eles, os idosos e, em seu artigo 59, prioriza a acessibilidade das pessoas com mobilidade reduzida(ITUIUTABA, 2018).

Diante destes cenários, pode-se verificar que as políticas públicas voltadas para atender a população idosa do município de Ituiutaba (MG) estão bem implementadas contando com vários órgãos e instituições, dentre eles o CRAS, um importante canal de acesso dos idosos às políticas públicas. Embora o CRAS não atenda somente a população idosa, ele se constitui em uma política pública voltada para a proteção social básica, que tem como objetivo prevenir situações de risco. 
Nele o idoso encontra atividades que melhoram sua saúde, promovem seu bem-estar e oferece alternativas para complementar sua renda.

Por ser, um espaço bastante frequentado por idosos que participam de seus projetos, bem como buscam benefícios e ajudas sociais, o CRAS foi o local escolhido para, mediante entrevistas individuais, entender como a população idosa de Ituiutaba avalia as políticas públicas, voltadas para elas e implementadas no município. Nesse contexto, a seguir serão demonstrados os resultados dessa pesquisa.

\section{A AVALIAÇÃO DOS IDOSOS SOBRE AS POLÍTICAS PÚBLICAS DE ITUIUTABA (MG)}

Os problemas relacionados ao envelhecimento não devem ser tratados somente com soluções paliativas, mas também com intervenções sociais, econômicas e ambientais. As dificuldades oriundas do envelhecimento, juntamente com o crescimento da população idosa, tornaram necessário o planejamento de políticas direcionadas às necessidades específicas dessa população. Nos últimos anos é perceptível o aumento da implementação de políticas sociais destinadas a atender e garantir direitos aos grupos sociais considerados vulneráveis ou de risco, os quais geralmente são compostos por cidadãos que possuem alguma carência social, política, biológica, econômica e/ou cultural.

É nesse contexto que surge o CRAS, realizando trabalhos de proteção social básica da população dos municípios onde estão inseridos. Assim como os demais locais voltados para a convivência e prestação de serviços, o CRAS é um espaço pensado e organizado considerando a população que reside tanto nos bairros onde ele está instalado, quanto nos que compõem o seu entorno. Em geral, localiza-se em territórios onde há maior vulnerabilidade e riscos sociais, prestando serviços e executando programas e projetos focados na família e na comunidade, conforme aponta o Ministério do Desenvolvimento Social (BRASIL, 2015).

Trata-se de um local público que reconhece os vários arranjos familiares, valoriza as especificidades de cada grupo familiar, fortalecendo vínculos e articulando-os com seu contexto comunitário. Ainda segundo o Ministério do Desenvolvimento Social (BRASIL, 2015), o CRAS é um programa de ação contínua, bem como uma política pública reconhecida como direito do cidadão. Embora a assistência social não consiga solucionar todos os problemas sociais e econômicos da população, ela é parte integrante da sua cidadania.

O CRAS é uma referência para a população local e para os serviços setoriais, atuando juntamente com a comunidade na busca de soluções para os problemas sociais comuns e na orientação quanto aos benefícios assistenciais a que os cidadãos têm direito. Sob a responsabilidade da SEDS, os CRAS ituiutabanos atendem tanto os moradores dos bairros onde estão implantados, como também os citadinos que moram nos bairros vizinhos, conforme os bairros localizados na área urbana do município. Baseados nos dados e informações coletadas foi possível apresentar a abrangência de cada CRAS (vide Figura 1) e demonstrar que a quantidade de CRAS existente no município de Ituiutaba é distribuída espacialmente, de forma que se permita a acolher toda a população, principalmente no que tange àquelas consideradas vulneráveis e expostas a riscos sociais. 
Figura 1 - Ituiutaba (MG): área de abrangência dos CRAS, 2019

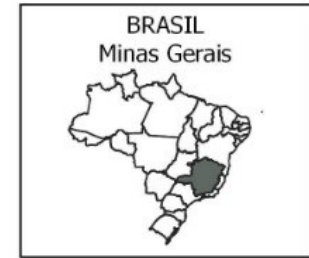

MINAS GERAIS Mesorregião do Triângulo Mineiro e Alto Paranaiba

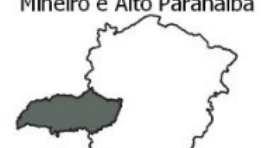

MESORREGIÄO DO TM. E A Microrregião de Ituiutaba

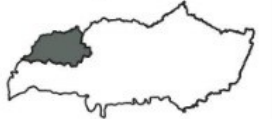

MICRORREGIÄO DE TUIUTABA
Município de Ituiutaba

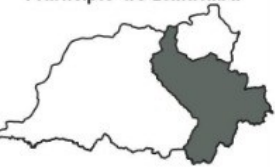

MUNICIPIO DE TUIUTABA Área Urbana de Ituiutaba
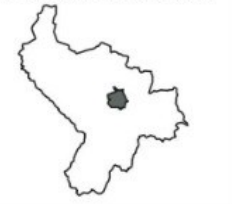

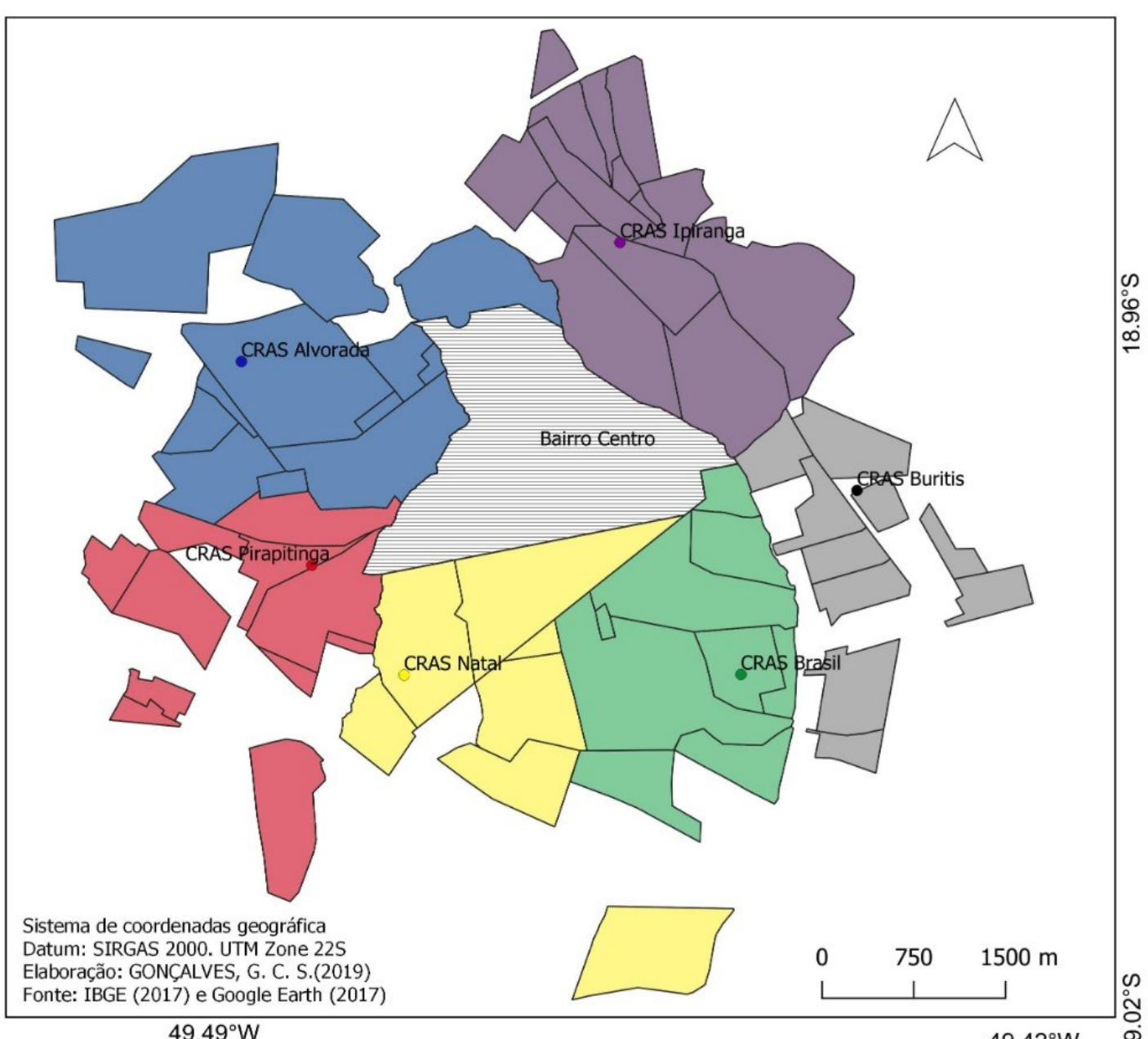

$49.42^{\circ} \mathrm{W} \quad$ ด

Fonte: IBGE, 2017 e Google Earth Pro, 2017. Elaboração: GONÇALVES, G. C. S., 2019.
Caminhos de Geografia
Uberlândia-MG
v. 21, n. 76
Ago/2020
p. $208-225$
Página 215 
As seis unidades recebem uma média de 1.000 (mil) pessoas/mês de diferentes faixas etárias e oferecem atividades voltadas para a convivência social, bem como acesso aos serviços e benefícios sociais, variando conforme a demanda de cada CRAS. Nos CRAS também são realizados projetos sociais voltados para os diferentes segmentos da sociedade. Segundo o gestor municipal ligado à SEDS, a mesma desenvolve nos CRAS o "Serviço de Convivência e Fortalecimento de Vínculos", onde são ofertadas oficinas de esporte, lazer e cultura, tais como: ginástica, dança, teatro, passeios turísticos, eventos (como o "Juninão" - festa junina), carnaval, bailes e outros; além de acompanhamento com estagiários dos cursos de Psicologia das instituições instaladas no município.

O quadro 1 auxilia na compreensão da figura 1, mostrando os bairros que são atendidos por cada CRAS e a população que cada um abrange.

Quadro 1 - Ituiutaba (MG): abrangência e população atendida dos CRAS, 2018

\begin{tabular}{|c|c|c|}
\hline CRAS & Abrangência & $\begin{array}{l}\text { População } \\
\text { atendida }\end{array}$ \\
\hline CRAS Natal & $\begin{array}{l}\text { Jerônimo Mendonça, Natal, Setor Sul, Nova Ituiutaba I, Nova Ituiutaba II, } \\
\text { Nova Ituiutaba III, Nova Ituiutaba VI, Santa Maria, Elândia, Gerson Baduy } \\
\text { I, Gerson Baduy II e Residencial Jardim Sul, abrangendo também, parte } \\
\text { do bairro Centro. }\end{array}$ & 14.842 habitantes \\
\hline CRAS Brasil & $\begin{array}{l}\text { Carvalho, Independência, Tupã, Eldorado, Brasil, Jardim do Rosário, } \\
\text { Camargo, Junqueira, Residencial Gilca Cancela, Residencial Ituiutaba, } \\
\text { abrangendo também, parte do bairro Centro. }\end{array}$ & 16.562 habitantes \\
\hline CRAS Alvorada & $\begin{array}{l}\text { Setor Norte, Satélite Andradina, Distrito Industrial, Alvorada, Novo Mundo, } \\
\text { Central, Hélio, Platina, Residencial Monte Verde, Lagoa Azul I, Jardim } \\
\text { Europa I, Jardim Europa II, Morada do Sol, Residencial Primavera, Jardim } \\
\text { Estados Unidos, Vivenda Almeida Drummond, Jardins das Mansões, Julia } \\
\text { de Paula, Estância Dona Viola, abrangendo também, parte do bairro } \\
\text { Centro. }\end{array}$ & 15.834 habitantes \\
\hline $\begin{array}{c}\text { CRAS } \\
\text { Pirapitinga }\end{array}$ & $\begin{array}{l}\text { Lagoa Azul II, Marta Helena, Residencial Copacabana, Residencial Dr. } \\
\text { Marcondes Bernardes Ferreira, Ribeiro, Guimarães, Pirapitinga, Mirim, } \\
\text { Jardim Jamila, Novo Tempo II, Residencial Carlos Dias Leite, Sol } \\
\text { Nascente, Prolongamento do bairro Sol Nascente II e Cidade Jardim. }\end{array}$ & 13.184 habitantes \\
\hline CRAS Ipiranga & $\begin{array}{l}\text { Universitário, Progresso, Ipiranga, Bela Vista, Cristina, Nossa Senhora } \\
\text { Aparecida, Maria Vilela, Santo Antônio, São José, Gardênia, Paranaíba, } \\
\text { Tiradentes, Setor Industrial Antônio Baduy, Residencial Drummond I, } \\
\text { Residencial Drummond II, abrangendo também, parte do bairro Centro. }\end{array}$ & 16.703 habitantes \\
\hline CRAS Buritis & $\begin{array}{l}\text { Residencial Buritis, Nadime Derze I, Nadime Derze II, Portal dos Ipês, } \\
\text { Residencial Canaã I, Residencial Canaã II, Esperança, Santa Edwiges, } \\
\text { Novo Horizonte e Setor Leste. }\end{array}$ & 9.091 habitantes \\
\hline
\end{tabular}

Fonte: SEDS, 2018. Elab. GONÇALVES, G. 2018.

Verifica-se que a população atendida é proporcional, exceto o CRAS Buritis que atende um número menor por contemplar uma população geograficamente mais afastada da área central e demais bairros. Além disso, conforme constatado nas entrevistas, o CRAS Buritis é uma instalação recente, com poucos usuários oriundos, inclusive, de outros CRAS. Observa-se, ainda, que o Bairro Centro, por haver uma grande quantidade de população, é abrangido por diferentes CRAS como: CRAS Alvorada, CRAS Brasil, CRAS Ipiranga e CRAS Natal. Além disso, o bairro Centro possui diferentes instrumentos destinados à Saúde como Hospital São José, Centro de Saúde da Mulher, dentre outros.

Com base nos levantamentos feitos é possível observar que a quantidade de CRAS instalados no município de Ituiutaba é suficiente para atender a demanda da sua população; porém, ainda é possível melhorar a estrutura deles, além de oferecer mais atividades e serviços mais eficientes àqueles que ali buscam pelo atendimento.

Para a realização da pesquisa, conforme já descrito na metodologia, foram entrevistados 153 (cento e cinquenta e três) idosos que frequentam os seis CRAS instalados no município de Ituiutaba (MG). As

$\begin{array}{lllll}\text { Caminhos de Geografia } \quad \text { Uberlândia-MG } & \text { v. 21, n. } 76 \quad \text { Ago/2020 } & \text { p. 208-225 Página } 216\end{array}$


entrevistas foram realizadas mediante preenchimento de formulário onde, inicialmente, foi levantado o perfil dos entrevistados, com o objetivo de melhor conhecer os idosos participantes. E, posteriormente, foi levantamento o entendimento desse grupo sobre as políticas públicas, conforme estabelecido no objetivo do trabalho. A quantidade de entrevistados em cada CRAS é proporcional ao número de idosos que participam das atividades oferecidas, uma vez que buscou-se realizar as entrevistas nos dias e horários de maior frequência dos mesmos nas atividades voltadas para eles. Percebeu-se que o baile ou forró que acontece em cada CRAS, em dias diferentes da semana, é a atividade mais popular entre os idosos.

Diante disso, a primeira análise a ser realizada foi referente ao perfil do idoso entrevista, onde constatou-se que no que se refere ao gênero é possível perceber, a partir da Tabela 1 , que a quantidade de participantes do gênero feminino $(75,8 \%)$ é predominante em todos os CRAS, o que pode acontecer em função das atividades oferecidas nos mesmos ainda ser, em sua maioria, consideradas femininas. Essa situação também pode se justificar porque o homem, mesmo aposentado, muitas vezes continua exercendo algum trabalho, principalmente por necessidade de complementar sua renda ou até mesmo a renda familiar.

Tabela 1 - Ituiutaba (MG): perfil dos idosos entrevistados nos CRAS, 2019

\begin{tabular}{lcccccc}
\hline \multicolumn{1}{c}{ CRAS } & $\begin{array}{c}\text { Quantidade } \\
\text { Entrevistados }\end{array}$ & \multicolumn{2}{c}{ Gênero } & \multicolumn{3}{c}{ Faixa Etária } \\
& & Feminino & Masculino & $\mathbf{6 0 - 7 0}$ & $\mathbf{7 1 - 8 0}$ & $>\mathbf{8 0}$ \\
\hline Alvorada & 24 & 21 & 3 & 14 & 8 & 2 \\
Brasil & 20 & 11 & 9 & 7 & 8 & 5 \\
Buritis & 10 & 9 & 1 & 3 & 7 & 0 \\
Ipiranga & 23 & 17 & 6 & 10 & 9 & 4 \\
Natal & 51 & 42 & 9 & 40 & 11 & 0 \\
Pirapitinga & 25 & 16 & 9 & 18 & 5 & 2 \\
\hline \multicolumn{1}{c}{ Total } & $\mathbf{1 5 3}$ & $\mathbf{1 1 6}$ & $\mathbf{3 7}$ & $\mathbf{9 2}$ & $\mathbf{4 8}$ & $\mathbf{1 3}$ \\
\hline
\end{tabular}

Fonte: Pesquisa direta, 2019.

Também foi possível identificar que os idosos que participaram da pesquisa estão, em sua maioria, na faixa etária dos 60 a 70 anos, totalizando $60,1 \%$ (vide Tabela 1). Por sua vez, apenas $8,5 \%$ dos participantes estão acima dos 80 anos. Na primeira faixa etária, o idoso ainda tem vigor e disposição para acompanhar as atividades; porém, a partir dos 80 anos, as dificuldades inerentes à mobilidade e aos problemas de saúde se agravam, dificultando tanto o acesso ao CRAS quanto o acompanhamento das atividades.

Vale ressaltar que tanto o transporte quanto a saúde foram problemas citados de forma recorrente durante a pesquisa, embora, quando entrevistados, tanto o gestor municipal quanto o representante do CMII afirmaram que o município possui programas específicos para a população idosa. Enquanto o gestor municipal citou como exemplo o atendimento prioritário a idosos e os programas executados pelo CRAS e PSFs, o representante do CMII citou tanto as ações promovidas pelo CRAS e ainda algumas ações realizadas por instituições particulares.

Quanto à escolaridade dos entrevistados, observou-se que $76 \%$ não completou o Ensino Fundamental (vide Tabela 1). Analisando esses dados juntamente com as informações colhidas durante as entrevistas, foi possível perceber que essa realidade se deve ao fato de que a geração das pessoas entrevistadas não tinha o estudo como prioridade; além disso, o acesso à educação era muito mais difícil, principalmente para aqueles que moravam nas zonas rurais ou que precisavam trabalhar ainda muito jovens para ajudar na renda familiar.

Conforme citado informalmente durante as entrevistas, os homens deixavam de estudar porque tinham que começar a trabalhar, seja para ajudar nas despesas da casa ou nos trabalhos rurais. As mulheres, por sua vez, eram em sua maioria impedidas pelos pais de irem para escola sob a alegação de que 
"Mulher não precisava estudar. Mulher tinha era que saber cuidar da lida da casa para poder casar". Essa fala foi bastante ouvida durante as entrevistas. Vale também relembrar que o número de mulheres entrevistadas foi bem maior que o de homens.

Embora o gestor municipal afirme haver programas de educação específicos para idosos, implementados no município, citando o programa de Inclusão Digital e o programa de Educação de Jovens e Adultos (EJA), durante as entrevistas com os idosos constatou-se um baixo interesse por esses programas. Apenas o EJA foi citado, mas por poucos idosos, levando a entender que a escolaridade não é um problema ou prioridade para a população idosa entrevistada.

O baixo número de analfabetos, somente 04 (quatro) entrevistados, ou seja, 2,15\% se destaca como um fator positivo, enquanto o fato de apenas 08 (oito) entrevistados $(6,72 \%)$ possuir curso superior também chama a atenção. A explicação pode estar no fato de que os mais favorecidos economicamente tinham maior acesso à educação, o que lhes permitiu cursar o ensino superior e se manter num patamar econômico melhor e, consequentemente, em sua velhice, os mesmos não precisam recorrer ao CRAS para ter acesso aos benefícios oferecidos pelo mesmo.

Analisando as profissões dos entrevistados, novamente o maior número de mulheres influencia os resultados, uma vez que a profissão que mais se destacou foi a "Do Lar/Doméstica", totalizando $44,26 \%$, reflexo do que foi citado anteriormente, ou seja, o baixo acesso das mesmas aos estudos e a criação voltada para o casamento e ao cuidado do lar. Também é preciso relatar que alguns idosos citaram como profissão "Aposentado", por entenderem tal situação como profissão. No geral, a maioria das profissões citadas não necessita de um alto grau de instrução, o que reforça a relação entre a escolaridade e a profissão dos idosos participantes desse estudo.

Conforme apontado no gráfico $1,63,5 \%$ daqueles que participaram desse estudo têm como renda apenas um salário mínimo, oriunda da aposentadoria, pensão ou do Benefício de Prestação Continuada (BPC). Embora a porcentagem daqueles que recebem acima de um salário mínimo seja 25,1\%, essa renda é composta em sua maioria por apenas dois salários mínimos pagos àqueles que são aposentados e, também, recebem uma pensão deixada pelo cônjuge. Em alguns casos, além da aposentadoria, o idoso faz algum outro trabalho para complementar sua renda.

Em função dessa realidade de baixa renda, o CRAS desenvolve um papel importantíssimo na vida do idoso, seja por oferecer atividades artesanais que complementam sua renda, seja na promoção de atividades que contribuem para o seu bem-estar e melhoria da sua saúde, uma vez que não teriam condições para pagar por esses benefícios em instituições particulares.

Gráfico 1 - Ituiutaba (MG): renda dos idosos entrevistados nos CRAS, 2019

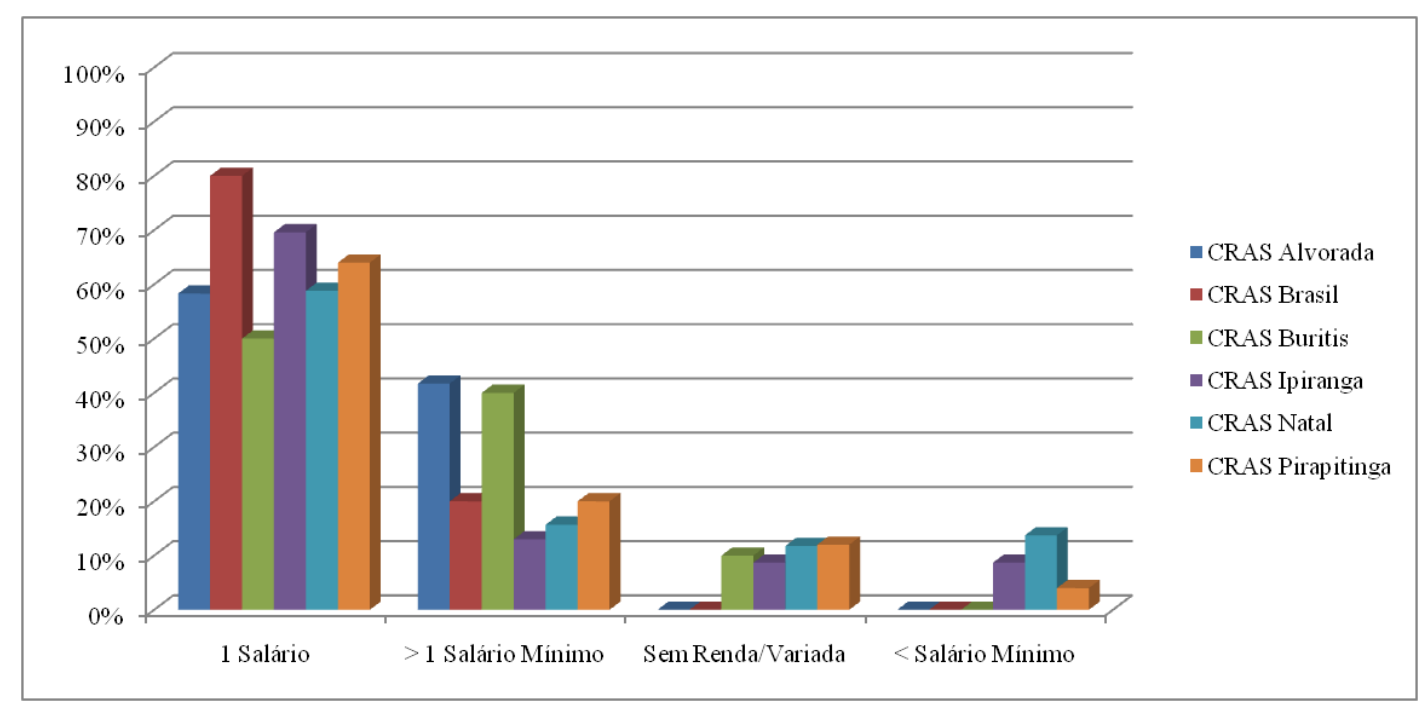

Fonte: Pesquisa direta, 2019. 
Em relação à moradia, a maioria dos idosos entrevistados (32,5\%) disseram que moram sozinhos. Esse percentual é maior do que o de idosos que moram com seus familiares $(28,7 \%)$ e daqueles que ainda moram com seu cônjuge ou companheiro(a) os quais compõem $22,9 \%$ do total de entrevistados, conforme mostra o Gráfico 2. O fato da maioria dos idosos morarem sozinhos reforça a ideia de que os mesmos buscam sua autonomia e independência, bem como, continuam ativos. Porém, em segundo lugar aparece o número de idosos que moram com seus familiares, seja em função da família ter a noção de responsabilidade para com os seus idosos ou pela necessidade financeira, tanto do idoso que não possui renda suficiente para se manter ou porque a família precisa complementar sua renda com os recebimentos do mesmo.

Avaliando agora o atendimento nos CRAS, foi realizada uma análise individual, ou seja, os idosos frequentadores do referido CRAS avaliou as atividades e serviços oferecidos, bem como a qualidade do espaço físico.

Começando pelo CRAS Alvorada pode-se verificar que dentre as atividades oferecidas, as mais citadas pelos 24 (vinte e quatro) participantes entrevistados foram: o baile (22), o crochê (21), a ginástica (19), o bordado (16), os passeios (14) e o corte e costura (12), como também o artesanato, os eventos, as palestras e o grupo de convivência, dentre outros.

Já no CRAS Brasil, as atividades mais citadas pelos 20 (vinte) idosos foram: a ginástica (15), os passeios (15) e o baile (15), assim como o artesanato, o Cadastro Único (instrumento utilizado pelo governo para identificar e registrar as famílias de baixa renda), a dança, a palestra, dentre outros.

Gráfico 2 - Ituiutaba (MG): com quem os idosos entrevistados moram, 2019

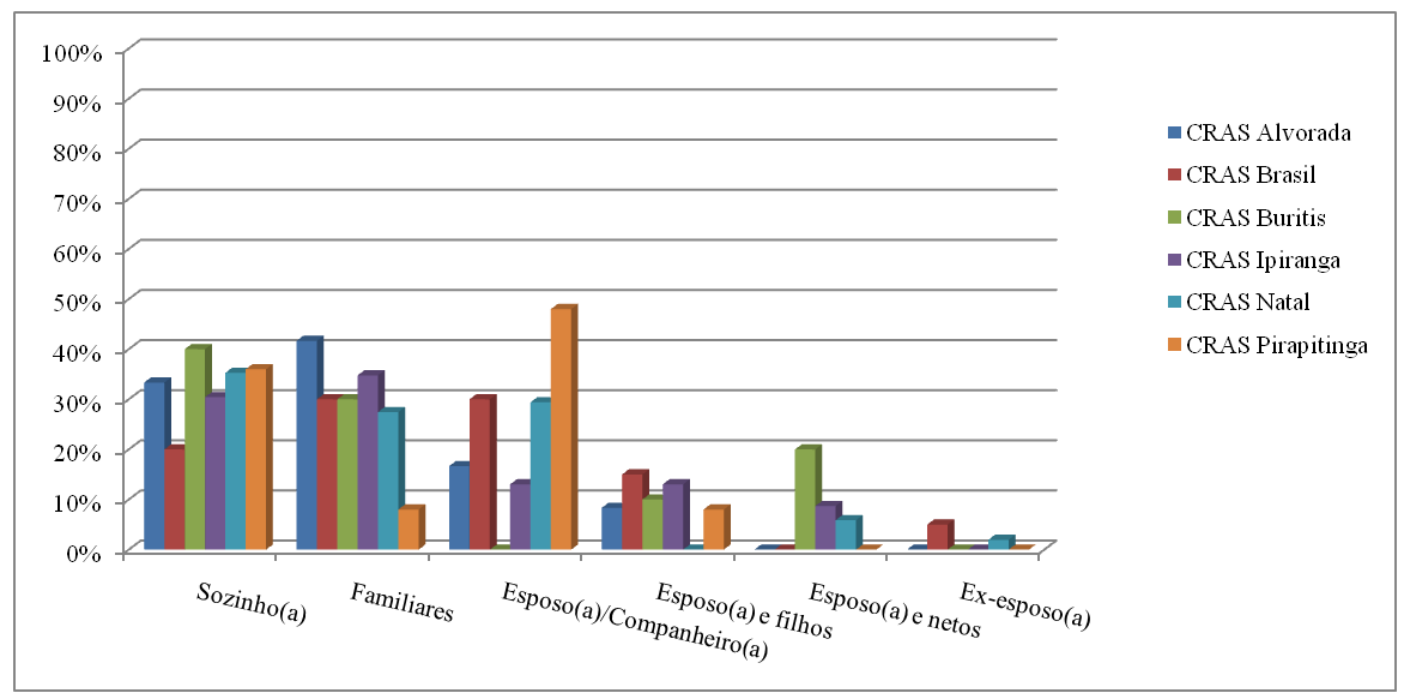

Fonte: Pesquisa direta, 2019.

No CRAS localizado no Bairro Buritis os 10 (dez) entrevistados mencionaram os passeios e a aferição de pressão como atividades de destaque na Instituição; 9 (nove) destacaram também as aulas de canto e a dança, 7 (sete) o artesanato, 6 (seis) a ginástica e 5 (cinco) o alongamento. Também foram citadas as atividades físicas, o crochê, os eventos e as palestras.

No CRAS Ipiranga foram entrevistados 23 (vinte três) idosos, dos quais 20 (vinte) elegeram a dança, 16 (dezesseis) o artesanato, 15 (quinze) os passeios, 13 (treze) o bordado e 11 (onze) as palestras como as atividades de maior destaque no CRAS. Os entrevistados também destacaram a aferição de pressão, o alongamento, as atividades físicas, os eventos, o grupo de convivência, a pintura, a terapia, dentre outros.

O CRAS localizado no Bairro Natal teve o maior número de idosos entrevistados, 51 (cinquenta e um) idosos. Acredita-se que esse maior número se deve ao fato de o mesmo ser uma das Instituições mais antigas do município e que atende uma maior parcela da população carente de Ituiutaba. Dentre as atividades de maior destaque no CRAS, 40 (quarenta) idosos citaram a dança, 31 (trinta e um) a 
ginástica, 28 (vinte e oito) o bordado e o crochê, 26 (vinte seis) as palestras, 22 (vinte dois) as atividades físicas, 21 (vinte um) o artesanato e 20 (vinte) o teatro. Também foram aludidos o programa Arte Recicla, as atividades de aferição de pressão, corte e costura e os passeios.

Por fim, dentre as atividades oferecidas pelo CRAS Pirapitinga, as mais citadas pelos 25 (vinte e cinco) idosos entrevistados foram o artesanato (24), o crochê (18), a dança (17), o bordado, os passeios (16 cada) e a ginástica (14). Também foram mencionados o baile, as palestras, o tricô, a zumba e as atividades físicas.

Diante desses dados, pode-se verificar que nos CRAS as atividades relacionadas à dança são as que despertam o maior interesse da população idosa. Acredita-se que isso se deva ao fato de, antes de ser instalado o CRAS no local, conhecido anteriormente como "Vaca Mecânica", ali eram realizados bailes frequentados em sua maioria pela população idosa, tornando o mesmo um espaço tradicional de dança.

Ao serem questionados sobre a importância da existência do CRAS, todos os entrevistados afirmaram que é uma instituição muito importante. Para eles, essa importância está ligada ao fato de encontrarem no CRAS um lugar de acolhimento e ajuda, o que pode ser exemplificado pela fala de um dos entrevistados: "Eu considero muito importante porque aqui cuido do meu corpo e da minha mente". Analisando as respostas obtidas, é possível constatar, também, que o CRAS é visto como um interessante canal de ajuda e bem-estar para o idoso, que encontra ali várias opções de lazer, além de uma oportunidade de socialização, o que pode ser comprovado também por uma das falas de um idoso entrevistado: "Para mim é (importante), porque oferece várias atividades e aí os idosos não ficam ociosos em casa. É importante pra saúde". O CRAS também se destaca pelo cuidado com a saúde do idoso, ao oferecer serviços de controle do diabetes e da pressão arterial, além de terapias e atividades físicas, como pode ser comprovado pela fala de outro entrevistado: "Muito, muito importante. Aqui eu tenho oportunidade de cuidar da minha saúde, mais perto de casa".

Embora considerado um local adequado para o idoso e um veículo de implementação das políticas públicas, o CRAS recebe reclamações quanto à sua estrutura, conforme mostra o Gráfico 3.

Gráfico 3 - Ituiutaba (MG): avaliação da estrutura do CRAS pelos idosos entrevistados, 2019

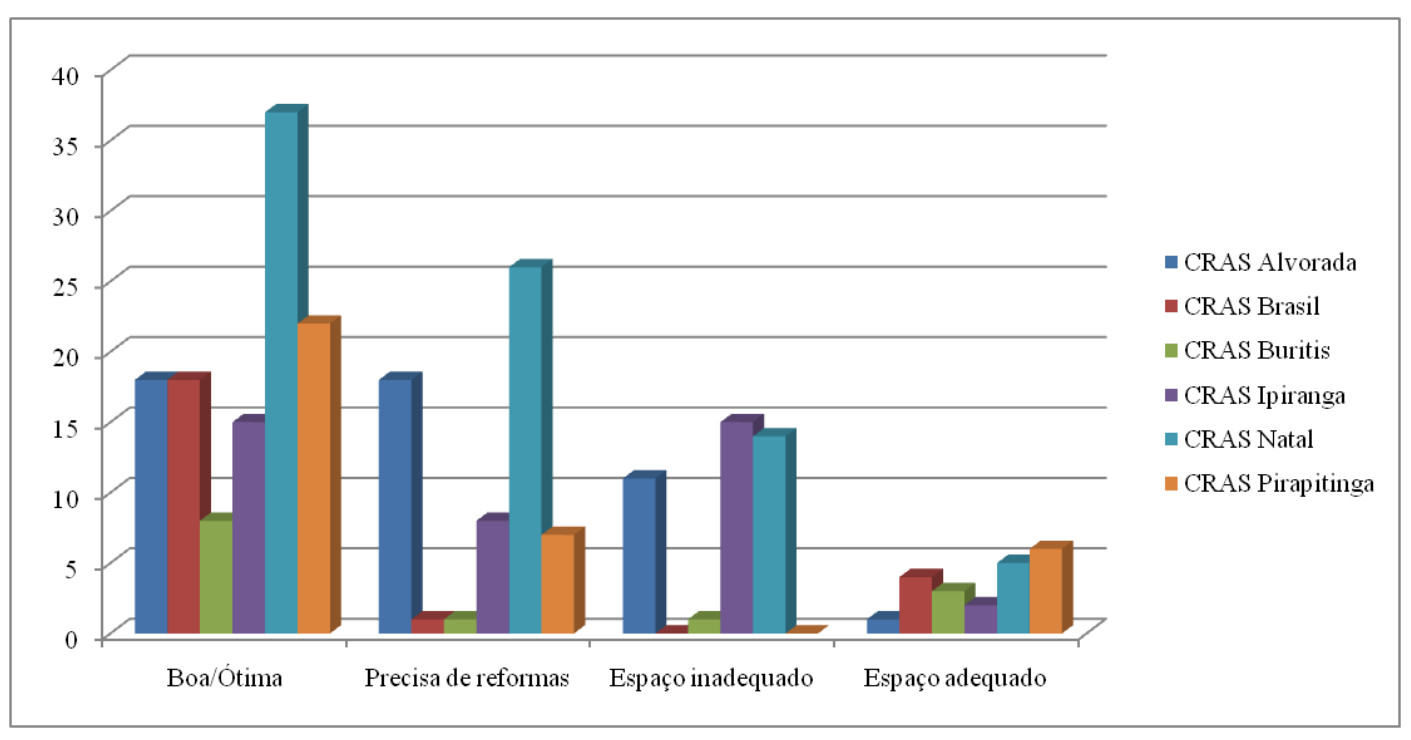

Fonte: Pesquisa direta, 2019.

Embora a maioria dos entrevistados considere a estrutura do CRAS que frequenta como boa ou ótima, bem como o espaço adequado, 102 (cento e dois) entrevistados afirmam que ela precisa de reformas, bem como consideram o local inadequado, ou seja, há problemas relacionados à falta de manutenção dessa estrutura. Dentre as queixas mais frequentes estão a falta de espaço, principalmente nos dias de baile ou forró, quando este se torna pequeno e sem ventilação adequada, como afirma a fala de um idoso: "Poderia melhorar aumentando o espaço. Quando junta todo mundo, fica muito apertado". 
Também foram apontados problemas em relação à estrutura inadequada, como destaca outro idoso: "Precisa de uma boa reforma. Os banheiros estão péssimos".

Quanto ao atendimento que os idosos recebem no CRAS, a maioria deles considera o mesmo como bom/muito bom ou como ótimo/excelente (conforme dados do Gráfico 4), ressaltando o bom atendimento dos funcionários, como destaca a fala de um idoso: "Ótimo. Sempre sou bem atendida. No geral, todos os funcionários atendem bem". A qualificação dos funcionários também foi ressaltada em outras falas, tais como: "Um ótimo atendimento com profissionais competentes e dedicados a tudo que fazem".

Gráfico 4 - Ituiutaba (MG): atendimento recebido no CRAS segundo os idosos entrevistados, 2019

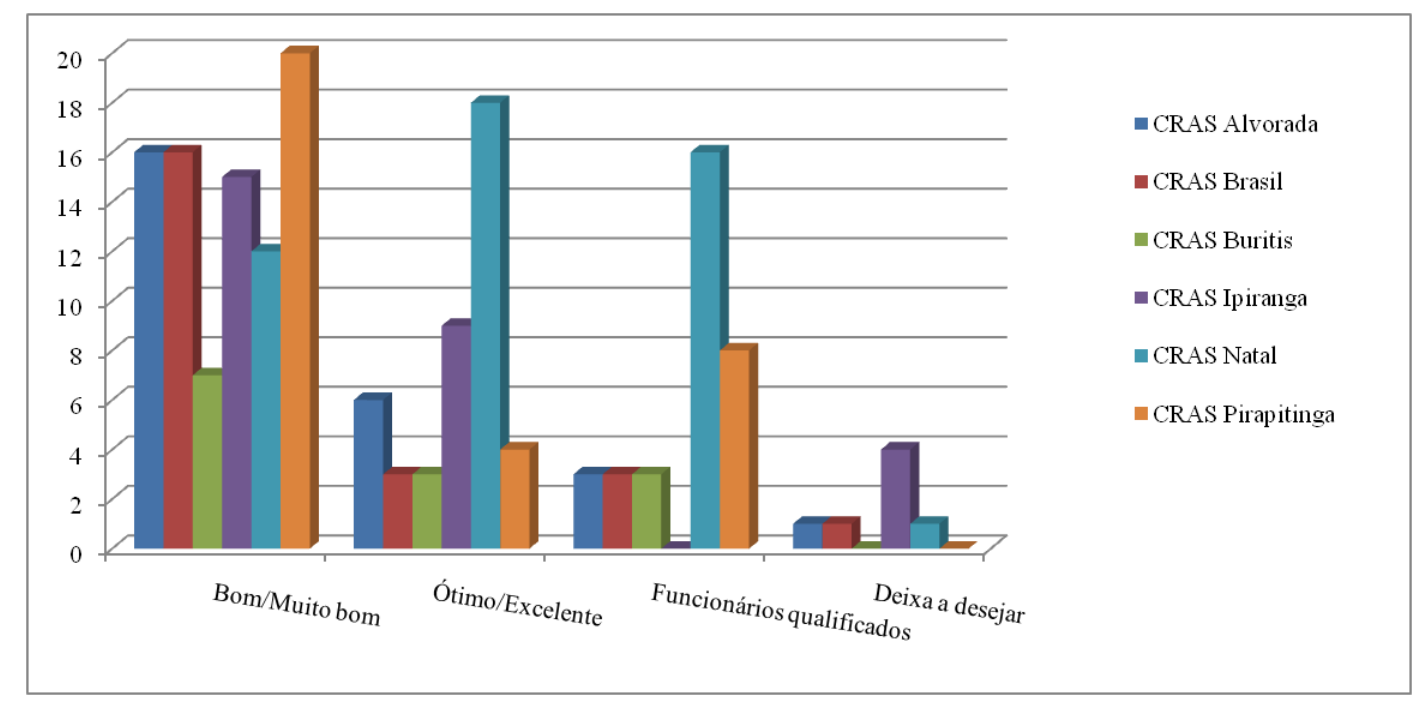

Fonte: Pesquisa direta, 2019.

Essa atenção especial ao atendimento do idoso parece ser uma preocupação do governo municipal e tais resultados demonstram que a gestão municipal está no caminho certo quanto ao atendimento oferecido nos CRAS, uma vez que o número de idosos que afirmaram que o atendimento deixa a desejar é bem pequeno diante do total de entrevistados e raras foram as falas tais como "O atendimento é bom, mas com exceções. Tem gente mal-educada aqui".

A mesma percepção de qualidade do atendimento também é observada nos serviços prestados pelo CRAS. A maioria dos idosos entrevistados (145 idosos), avaliaram positivamente os serviços recebidos, considerando bom/muito bom e ótimo/excelente. Alguns usuários buscam no CRAS inclusive melhorias na saúde, como pode ser avaliado pela fala dos próprios idosos: "O serviço é ótimo. Se não fosse ele, nossa saúde estaria pior". A qualificação dos funcionários também foi citada, como destaca a fala de outro idoso entrevistado: "Muito bom. Somos atendidos por profissionais muito competentes". Embora em pequena quantidade, alguns idosos afirmaram que a prestação de serviços pelo CRAS pode melhorar: "Poderia melhorar. Podia ter mais atividades. Algumas atividades estão paradas por falta de monitores". Também houve em pequena quantidade, reclamações tais como: "Às vezes, para conseguirmos uma cesta básica, temos que implorar".

Portanto, é perceptível a importância do CRAS como canal de acesso às políticas públicas voltadas para a população idosa, bem como um importante espaço de acolhimento dela, desempenhando um importante papel na socialização e bem-estar do idoso.

\section{A PERCEPÇÃO DOS IDOSOS SOBRE AS POLÍTICAS PÚBLICAS IMPLEMENTADAS EM ITUIUTABA/MG}

Visando responder a um dos objetivos específicos dessa pesquisa, durante a aplicação dos formulários questionou-se esses idosos sobre o entendimento deles acerca das políticas públicas. Ficou nítido, diante das respostas, que muitos desconhecem o assunto enquanto outros confundem políticas

$\begin{array}{lllll}\text { Caminhos de Geografia } & \text { Uberlândia-MG } & \text { v. 21, n. } 76 & \text { Ago/2020 } & \text { p. 208-230 Página } 221\end{array}$


públicas com a política em si. Essa afirmação pode ser comprovada ao se obter respostas tais como: "Já ouvi falar, mas eu não gosto nem de falar sobre política" ou "Não entendo nada. Detesto política". Porém, também foram obtidas retornos interessantes de idosos que entendiam que as políticas públicas são os direitos a eles assegurados mediante as leis: "São as ações do governo para melhorar a qualidade de vida das pessoas" e "Políticas públicas são as leis que os idosos têm direito".

No geral, muitos disseram já terem "ouvido falar", principalmente na televisão, mas não tinham interesse sobre o assunto nem sabiam falar sobre ele. Porém, como a maioria não entende ao certo do que se tratam as políticas públicas, eles acham que a saúde e o transporte são os itens mais importantes, tornando os mesmos recorrentes em suas respostas.

O gráfico 5 ilustra essa realidade, onde a maioria não sabe/não entende nada ou entende pouco sobre o que realmente sejam as políticas públicas. Uma parte confunde tais políticas com a política em geral citando a corrupção como motivo para detestar o assunto: "Não gosto de discutir sobre política" e "Detesto esse assunto. Os políticos só querem saber do nosso voto e de roubarem". Uma pequena parte, porém, sabe que as políticas públicas estão relacionadas com as leis e direitos da população, embora não sejam efetivadas na prática: "São os direitos que temos" e "São as leis e os regimentos criados mas não saem do papel, porque a gente nem sabe dos direitos que tem".

Gráfico 5 - Ituiutaba (MG): o que os idosos entrevistados entendem/sabem sobre políticas públicas, 2019

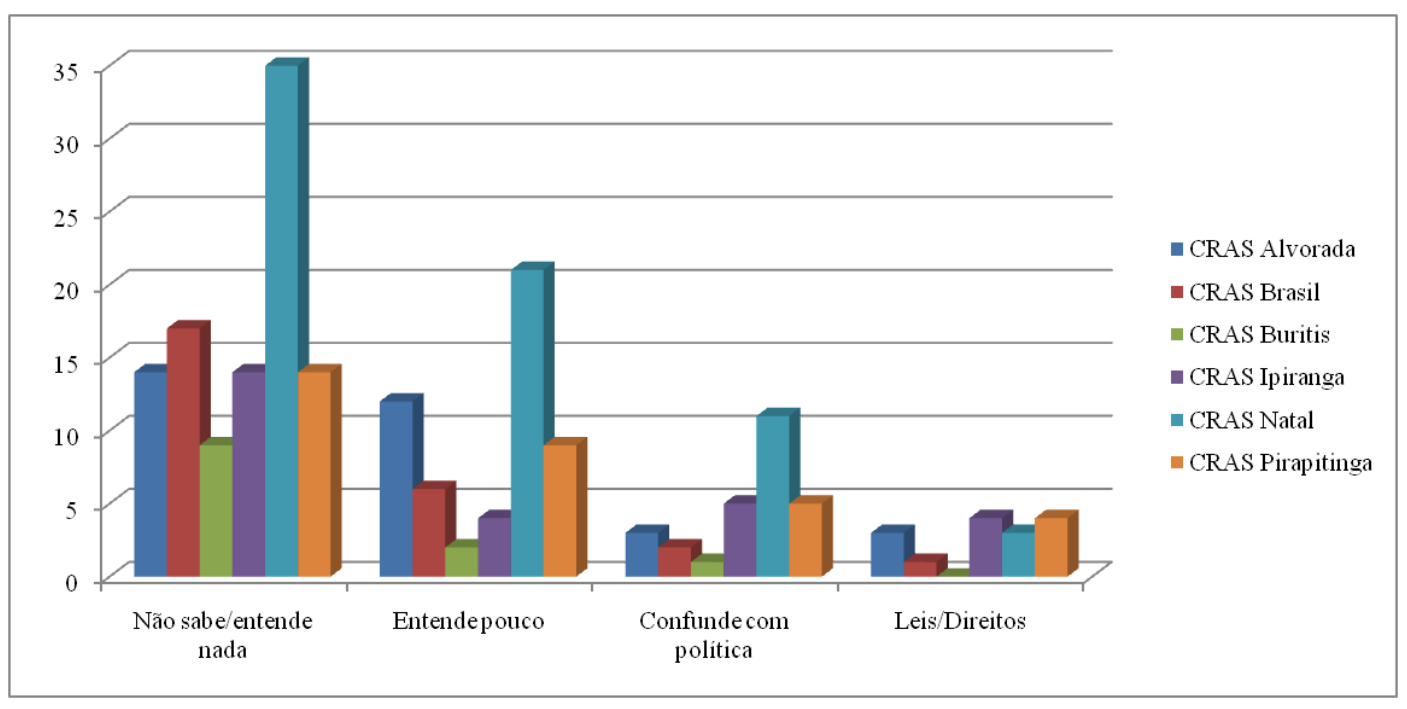

Fonte: Pesquisa direta, 2019.

O transporte e a saúde foram os mais citados como políticas públicas conhecidas, seguidos do atendimento preferencial juntamente com a aposentadoria e os benefícios sociais. Vale ressaltar que o estacionamento exclusivo para idosos foi citado juntamente com a preferência nos atendimentos. Infelizmente, embora alguns deles participem do programa EJA, o mesmo quase não foi citado, assim como o Estatuto do Idoso, principal legislação que garante os direitos da população idosa. Mesmo após a explicação do que seriam as políticas públicas, alguns entrevistados afirmaram não conhecer nenhuma delas. Esse cenário é ilustrado pelo gráfico 6 , que mostra claramente a percepção de que, para os participantes, o transporte é mais importante que a saúde em praticamente todos os CRAS, ou seja, enquanto 234 (duzentos e trinta e quatro) citaram conhecer o transporte, 201 (duzentos e um) entrevistados afirmaram conhecer a saúde.

Porém, é possível observar no gráfico 6 que a saúde é mais utilizada por esses participantes, o que parece uma incoerência. Talvez essa observação seja devido ao fato de que o transporte seja uma necessidade recorrente e cotidiana, enquanto a saúde seja necessidade esporádica. Assim, como a precisão de um atendimento médico é esporádica, parece claro que o idoso não percebe a prioridade da saúde em sua vida. 
Gráfico 6 - Ituiutaba (MG): políticas públicas que os idosos entrevistados conhecem, 2019

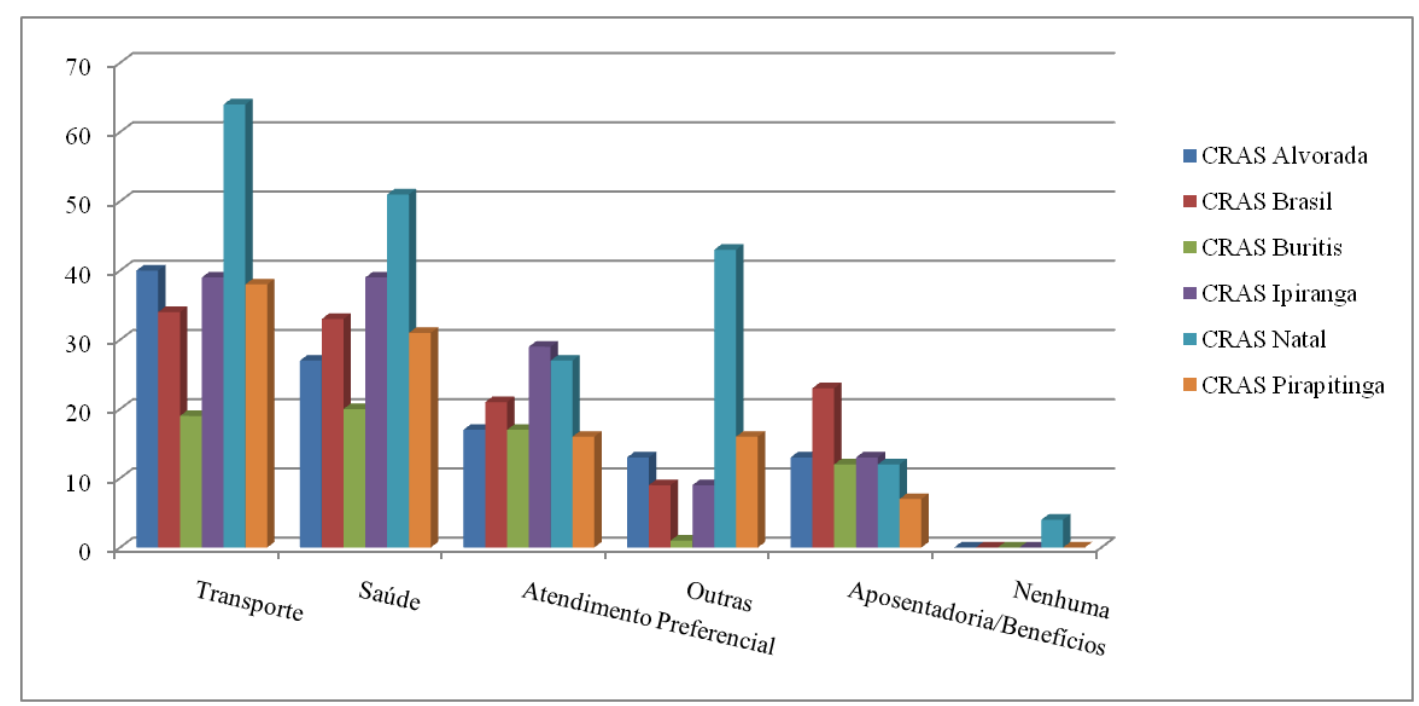

Fonte: Pesquisa direta, 2019.

Cabe ressaltar que os atendimentos preferenciais e o estacionamento exclusivo para idosos também foi citado por muitos participantes (127), bem como a aposentadoria e os benefícios sociais, totalizando 80 (oitenta) idosos.

Quanto as políticas públicas que os idosos usufruem, o gráfico 7 apresenta a mesma tendência do gráfico anterior, exceto a inversão entre transporte e saúde como mais citados. Isso demonstra que os idosos conhecem praticamente as políticas públicas que eles usufruem. Ao pedir que os entrevistados avaliassem as políticas públicas voltadas para a população idosa ficou bem claro, conforme apresentado no gráfico 8 , que a saúde e o transporte são os tópicos de maior interesse daqueles que participaram da pesquisa.

Embora a maioria tenha afirmado que, no geral, as políticas públicas que atendem os idosos funcionam bem, muitos citaram que os serviços de saúde e transporte estão ruins ou péssimos. Falas tais com: "O SUS é complicado". "Faltam médicos e remédios". "Demora para conseguir consultas e exames". "O transporte coletivo deixa muito a desejar". "Os motoristas não têm paciência". "Os lugares pros idosos são poucos"; "O transporte coletivo precisa melhorar. "Os lugares são poucos e os motoristas estão sempre com pressa". "Já o SUS e o PSF têm filas longas. Faltam médicos e remédios e os exames são demorados"; e "O transporte coletivo é muito restrito, se não tiver lugar na frente, eles nem param no ponto; no SUS é complicado de ser atendido; e nem sempre conseguimos a passagem quando queremos", foram bastante citadas.

Enquanto poucos não souberam opinar, alguns disseram que tais políticas públicas não funcionam bem e precisam melhorar. Muitos alegam que, embora elas existam no papel, muitas não são cumpridas ou respeitadas. As falas "Pode melhorar, principalmente o SUS. Eu não tenho muito que reclamar, mas sei de idosos que passam dificuldades"; "Ainda falta muito respeito"; e "Tem coisas que precisa funcionar melhor. Na televisão eles falam que tem muitas coisas pros idosos, mas na prática, tem muito idoso jogado às traças", comprovam isso. 
7 - Ituiutaba (MG): políticas públicas que os idosos entrevistados usufruem, 2019

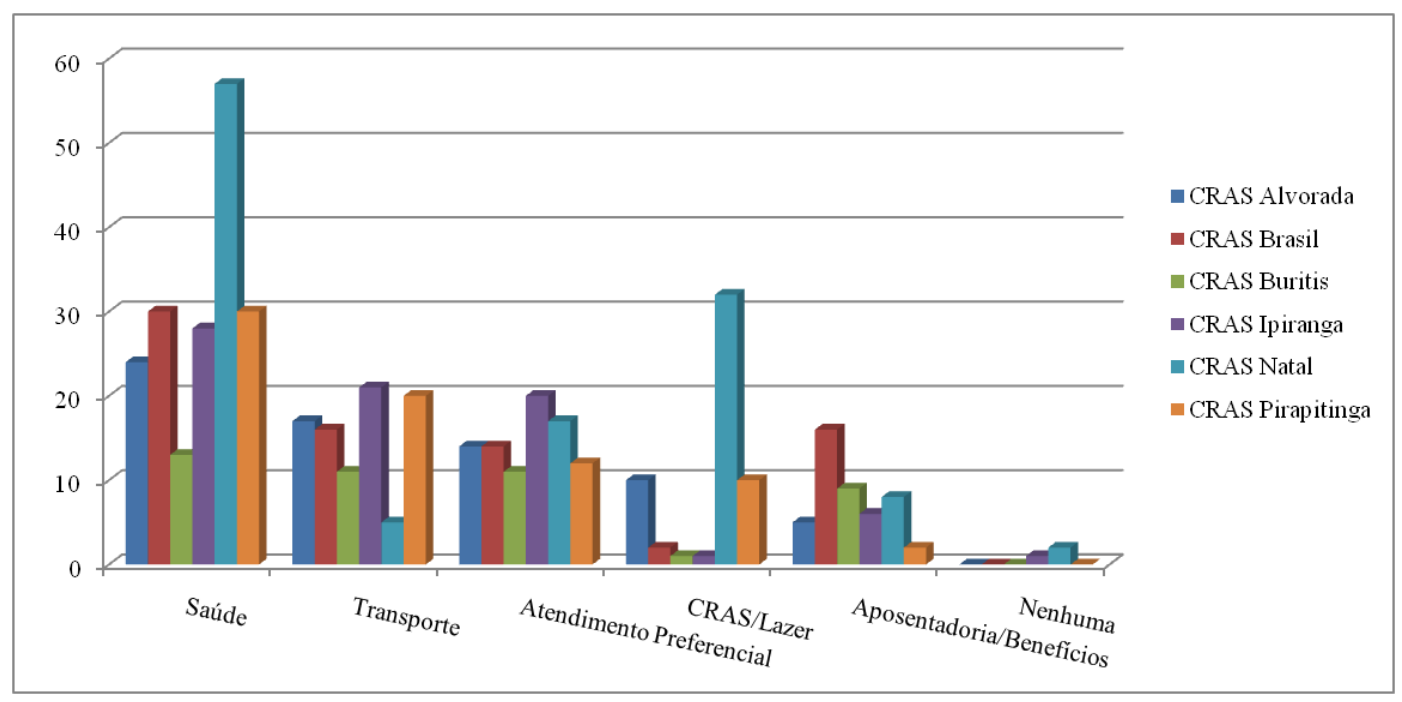

Fonte: Pesquisa direta, 2019.

Gráfico 8 - Ituiutaba (MG): avaliação das políticas públicas pelos idosos entrevistados, 2019

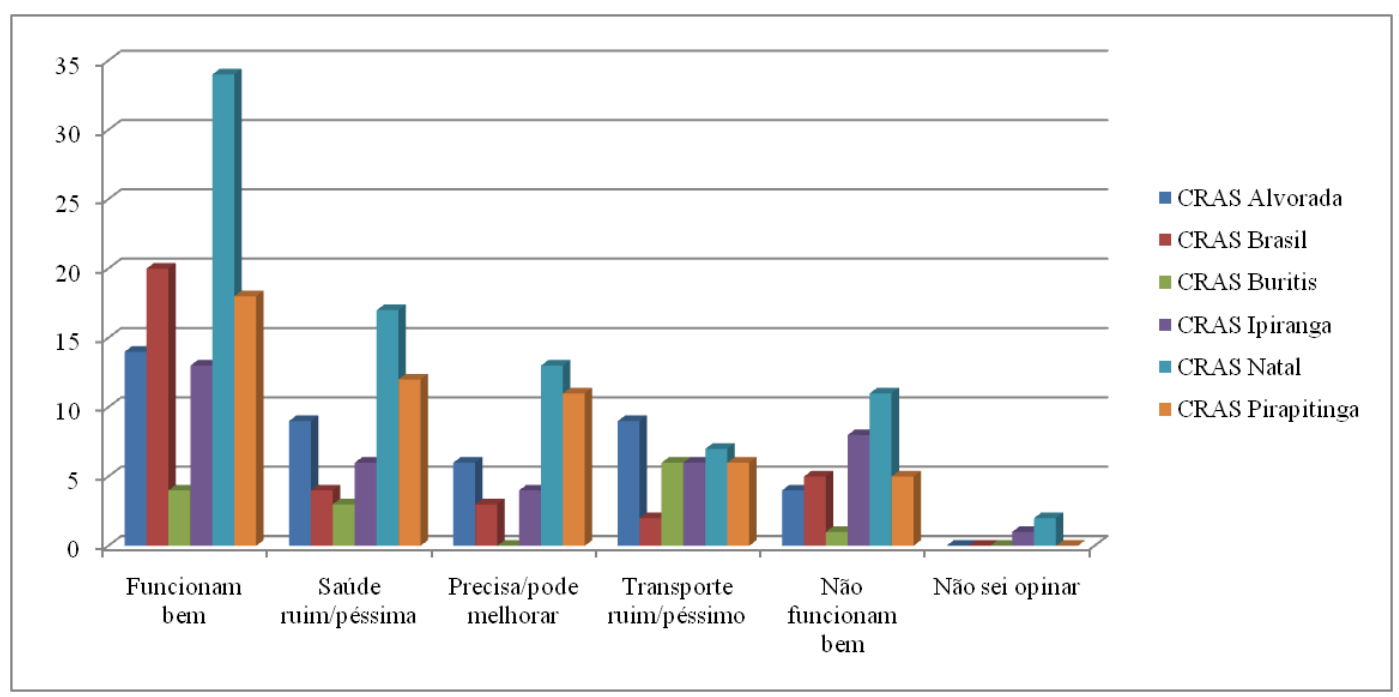

Fonte: Pesquisa direta, 2019.

Ainda em relação ao serviço de transporte, muitos idosos reclamaram que, embora a legislação garanta a sua gratuidade para idosos acima de 60 anos, em Ituiutaba a mesma só é garantida para aqueles que já completaram 65 anos. Além disso, o número de vagas destinadas aos idosos são limitadas. Caso os assentos reservados aos mesmos já tenham sido ocupados, os idosos precisam pagar a passagem ou são impedidos de utilizarem o transporte. "Podia melhorar muito, principalmente para os idosos com menos de 65 anos. Nós não temos direito a transporte e passagens gratuitas"; "Os motoristas dos coletivos são mal-educados e apressados. As vagas para os idosos são muito poucas. Aí ou ficamos muito tempo esperando ou pagamos a passagem"; e "Quando as vagas do coletivo estão ocupadas, ou pagamos ou temos que esperar outro ônibus. Isso nos humilha bastante", são algumas das falas que exemplificam essa realidade.

Porém, essa realidade é antagônica à fala do gestor municipal durante sua entrevista, uma vez que o mesmo afirma que a gratuidade nos transportes coletivos, garantida legalmente, funciona de maneira efetiva. No entanto, o representante do CMII contradiz o gestor, ao afirmar que "Ainda há muitas falhas

$\begin{array}{lllll}\text { Caminhos de Geografia } \quad \text { Uberlândia-MG } & \text { v. 21, n. } 76 \quad \text { Ago/2020 } & \text { p. 208-230 Página } 224\end{array}$


e reclamações, apesar da lei. Principalmente no que se refere ao atendimento dos motoristas", corroborando com a fala dos entrevistados.

Por ser uma das principais leis que garante ao idoso, autonomia, direitos e participação social, além de tratar sobre sua proteção e cidadania, buscou-se conhecer o que o idoso conhece sobre o Estatuto do Idoso. Analisando as respostas obtidas, constatou-se que uma grande parcela dos entrevistados (74) não sabe nem entende nada sobre o assunto. Porém, uma boa parte já ouviu falar e sabe que se trata de leis, direitos e orientações voltadas para os idosos e que os beneficiam de alguma forma. Já no outro extremo, apenas um dos entrevistados afirmou conhecer e entender sobre o Estatuto do Idoso enquanto 12 (doze) idosos afirmaram nunca terem ouvido falar sobre o mesmo.

Ao avaliarem a implementação das políticas públicas voltadas para a população idosa, no município de Ituiutaba, $11 \%$ dos idosos entrevistados consideraram o cenário como bom/muito bom. Porém, uma porcentagem próxima $(9,5 \%)$, afirmou que essa implementação precisa melhorar. Boa parte também considerou a mesma como precária ou péssima, totalizando $7 \%$ dos entrevistados. A referência à qualidade ruim tanto da saúde quanto do transporte é recorrente também nesse item, como mostra o gráfico 9 , demonstrando que as ações ligadas a essas duas políticas públicas se destacam das demais.

Gráfico 9 - Ituiutaba (MG): avaliação dos idosos entrevistados sobre as políticas públicas no município, 2019

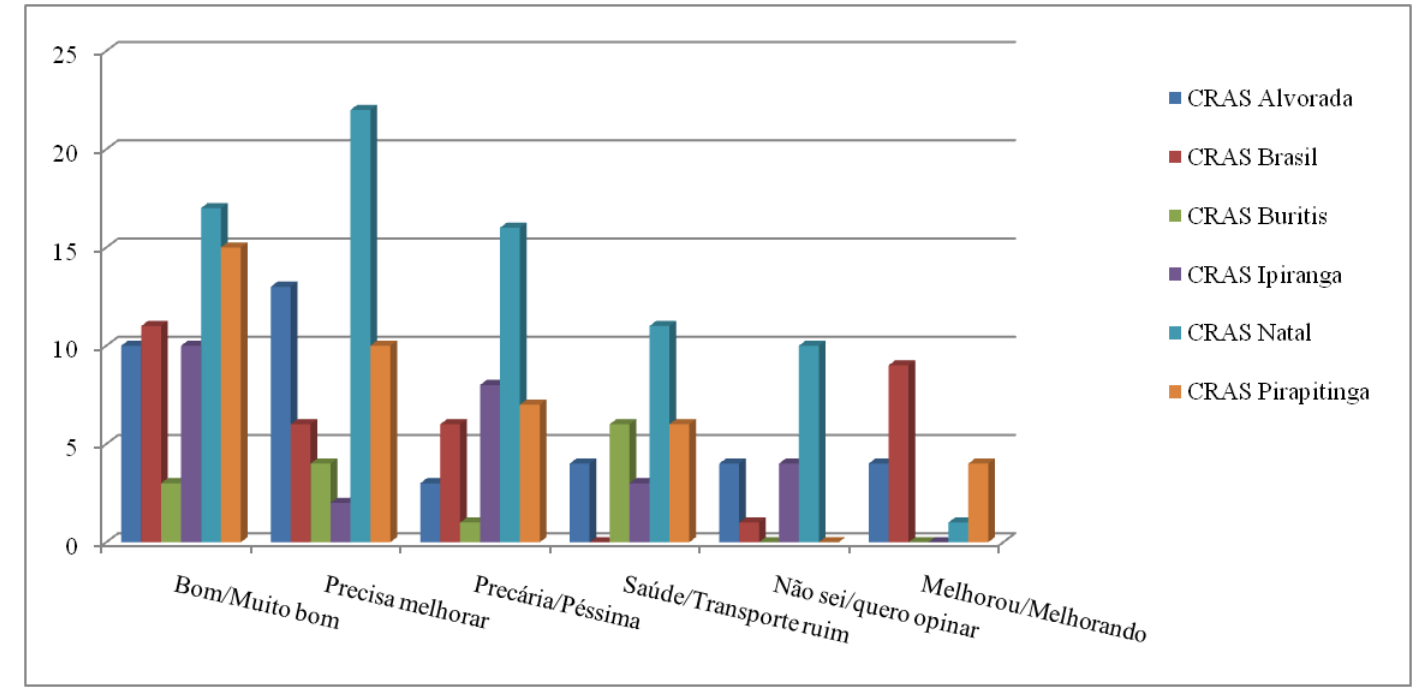

Fonte: Pesquisa direta, 2019.

Quanto à saúde, durante a entrevista com o representante do CMII, o mesmo afirmou saber da existência de ações voltadas para a saúde do idoso implementadas pelo Poder Municipal, porém disse não ter conhecimento de suas especificidades. Já o gestor municipal apontou como tais ações: promoção à saúde; palestras; programa Hiperdia (destinado ao cadastramento e acompanhamento de portadores de hipertensão arterial e/ou diabetes mellitus), onde a maior adesão são de idosos; ações com o NASF (Núcleo de Apoio à Saúde da Família), danças, alongamentos e automassagem. O gestor afirmou ainda que é dado prioridade aos atendimentos dos idosos, inclusive com agendamento de consultas via telefone. Por fim, alguns entrevistados disseram não saber ou não quiseram opinar sobre a questão, enquanto outros poucos afirmaram que a implementação das políticas públicas municipais está melhorando ou já melhorou com a nova gestão.

O formulário de pesquisa também trouxe o questionamento sobre quais políticas públicas voltadas para a população idosa, o entrevistado acha que deveriam ser implementadas no município de Ituiutaba. Essa pergunta visa alcançar um dos objetivos propostos neste trabalho, que é indicar quais dessas políticas ainda devem ser efetivadas no município. O Gráfico 10 representa as respostas obtidas nesse momento.

Pode-se verificar que nas respostas dos entrevistados aparece uma preocupação maior com os cuidados exclusivos/individualizados para os idosos, representada pelo o que pode ser comprovado

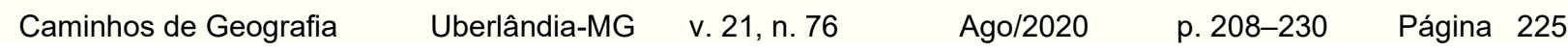


por algumas falas: "Um espaço exclusivo para atender os idosos com a parte de saúde e outras atividades de convivência. Também podia ter uma creche para os idosos"; "Sinto falta de um espaço só para atender os idosos (saúde, lazer, convivência...)"; e "Precisava ter um atendimento exclusivo para os idosos, principalmente para aqueles que têm dificuldades de locomoção".

Embora reconheçam a importância do CRAS para a prática de atividades físicas e o acesso ao lazer, os entrevistados também afirmaram sentirem falta de outras atividades tais como hidroginástica, um espaço de lazer só para eles, mais passeios, dentre outros: "Uma área de lazer só para os idosos. Os idosos gostam muito de festas e diversão"; "Mais espaços de lazer. Chega no domingo, o idoso não tem onde ir pra se divertir"; e "Mais espaço de lazer e um espaço de convivência só para nós que somos idosos".

Gráfico 10 - Ituiutaba (MG): políticas públicas que deveriam ser implementadas, segundo a visão dos idosos entrevistados, 2019

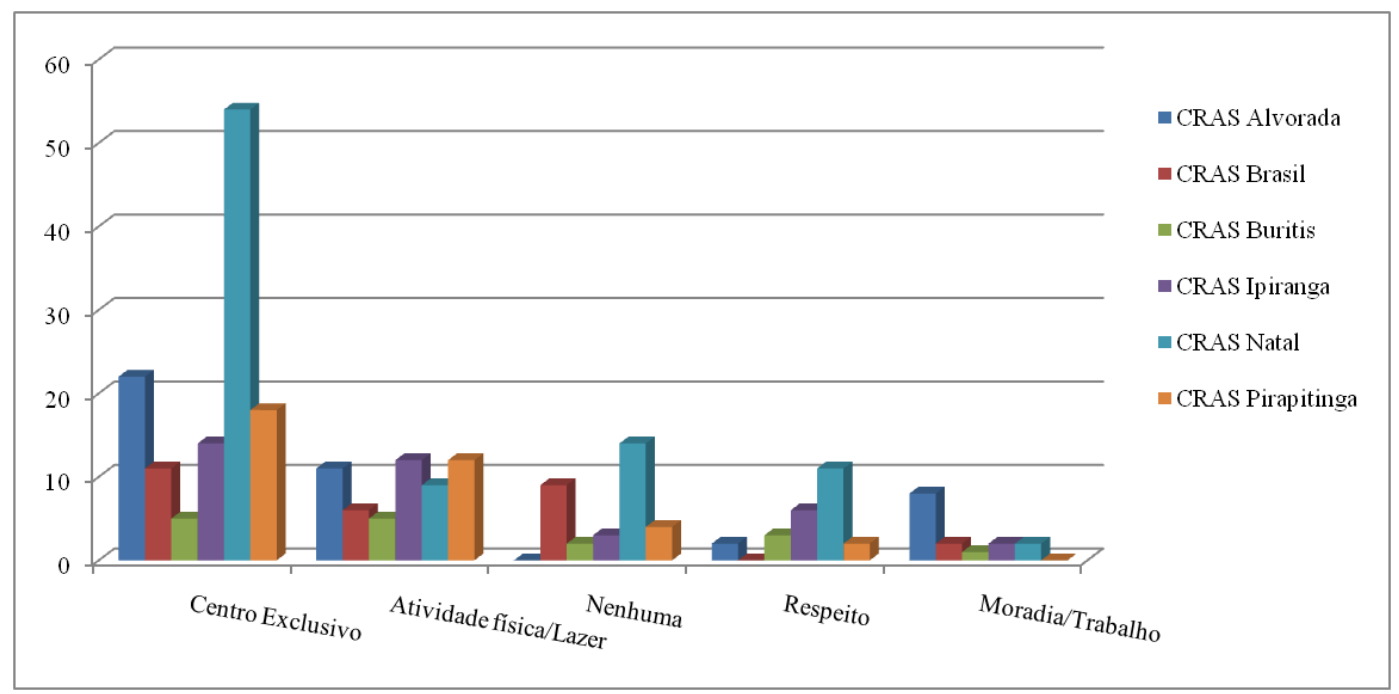

Fonte: Pesquisa direta, 2019.

Um número expressivo, ou seja, 32 (trinta e dois) idosos afirmaram não saberem citar nenhuma política que deveria ser implementada, o que pode ser justificado pelo desconhecimento, já abordado anteriormente, do que sejam as políticas públicas. Além disso, não se sente falta daquilo que nunca se teve.

Os temas saúde e transporte também foram citados nesse momento. A saúde aparece nas reivindicações de um espaço para atendimento exclusivo dos idosos, uma vez que em muitas situações os mesmos precisam aguardar atendimento junto com todos os demais pacientes. Além disso, há a dificuldade de locomoção, a saúde frágil e a demora para se conseguir consultas, exames e remédios: "Precisa ter um atendimento mais exclusivo pro idoso, pra evitar as filas na saúde"; "Os idosos deveriam ter prioridade em todos os atendimentos da saúde. Não acho certo a gente ser atendido do mesmo jeito que os mais novos"; e "Lugares onde os idosos tivessem realmente prioridade tanto na saúde quanto nos demais serviços. Também precisavam ver a questão da acessibilidade".

Já o transporte aparece no quesito respeito, uma vez que grande parte das reclamações tem a ver com o comportamento dos motoristas apressados e muitas vezes mal-educados. Há também o problema já citado referente ao número reduzido de assentos disponibilizados para os idosos, bem como a gratuidade do serviço apenas para idosos acima dos 65 anos: "Como não participo de muita coisa, acho difícil responder. Mas penso que o transporte coletivo gratuito precisa ser pra pessoas acima de 60 anos, como manda a lei, e não acima de 65 anos"; "Melhorar o transporte coletivo"; e "Colocar transporte coletivo gratuito para pessoas com 60 anos ou mais; criar um local para atender só os idosos na área da saúde; ter um local para hidroginástica".

A questão do respeito tanto aos idosos quanto aos direitos deles também foi apresentada por alguns entrevistados em relação à implementação de políticas públicas: "Se as que têm funcionassem, já

$\begin{array}{lllll}\text { Caminhos de Geografia } & \text { Uberlândia-MG } & \text { v. 21, n. 76 } & \text { Ago/2020 } & \text { p. 208-230 Página } 226\end{array}$


estaria bom"; "Mais respeito. Melhor tratamento em todos os sentidos"; e "Falta muita coisa. Mas, se respeitassem nossos direitos já estaria ótimo".

Por fim, foram citadas também as questões relativas à moradia e ao trabalho. Embora o artigo 37 do Estatuto do Idoso cite a moradia digna como um direito do idoso e o seu artigo 38 assegure a sua prioridade na aquisição de imóveis, na prática, muitos idosos não possuem uma moradia, sendo obrigados a viverem de favor em casa de familiares, ir para uma instituição de longa permanência ou, até mesmo pagarem aluguel. Essa realidade aparece em falas tais como: "Podia ter um programa de moradia pro idoso. Muitas vezes o idoso ganha um salário e tem que pagar aluguel. Também faltam remédios e médicos"; "Falta um programa de moradia e um lugar para cuidar da saúde só dos idosos"; e "Um programa de casas para os idosos que ainda pagam aluguel".

Quanto ao trabalho, conforme já abordado anteriormente, mesmo na velhice alguns idosos precisam trabalhar, uma vez que muitos são os gastos nessa fase da vida, principalmente com medicamentos, bem como com a saúde em geral. Tais gastos seriam minimizados se políticas públicas de saúde, moradia e transporte funcionassem de forma a atender as necessidades dessa parcela da população. Além disso, como já apresentado anteriormente, atualmente o idoso precisa contribuir com a renda familiar e, muitas vezes a renda oriunda da aposentadoria, pensão ou benefício não é suficiente para sanar todas as necessidades.

Assim, fazem-se necessárias políticas públicas que facilitem o acesso desse idoso ao mercado de trabalho. Essa necessidade aparece em falas como: "Oportunidade de trabalho, muitos precisam de renda. Também podia ter mais academias ao ar livre" e "Mais lazer, atividades de convivência. Mais cursos, tipo artesanato, que ajudassem a melhorar nossa renda".

Ao final das entrevistas, foi aberto para que os entrevistados, caso quisessem, fizessem suas considerações finais. Nesse momento, ficou claro na fala dos mesmos que eles sentem falta do cuidado, respeito e prioridade, tanto para com eles mesmos quanto para com seus direitos: "Eu penso que falta muito respeito com os idosos e com os nossos direitos"; "As pessoas precisam tem mais consideração para com os idosos e pensarem no seu futuro"; "O idoso precisa ser muito mais respeitado. Ituiutaba tem muitos idosos, então as pessoas precisam aprender a lidar com essa situação"; e "Os governos precisam pensar mais nos idosos. A gente já trabalhou muito e contribuiu muito também. A gente merece um pouco mais de cuidado".

Uma questão interessante é que, novamente, a saúde e o transporte foram citados, bem como suas falhas e deficiências, demonstrando que os mesmos são direitos considerados muito importantes para a população idosa: "Os idosos precisam ser mais respeitados. O transporte coletivo deveria ser gratuito para pessoas acima de 60 anos"; "Falta melhorar o atendimento nas filas dos idosos; ter médicos nos PSFs; ter os medicamentos... As passagens nunca têm e os motoristas precisam ser mais atenciosos..."; "O transporte coletivo não funciona. Se os lugares dos idosos estiverem lotados, a gente não pode entrar pela porta traseira, temos que pagar passagem"; e "Na saúde: consultas são marcadas com 30 até 60 dias, exames médicos cardíacos são marcados até com 12 meses, isso não pode, mas é o que acontece. Não contando que as consultas têm que dormir nos postos de atendimento para conseguir marcar".

Os idosos também reclamaram da falta de divulgação dos seus direitos, bem como solicitaram que fossem realizadas palestras e discussões sobre o tema da pesquisa. Portanto, posteriormente pretende-se apresentar os resultados dessa pesquisa em cada um dos CRAS, bem como às autoridades responsáveis pelos cuidados e atendimentos aos idosos de Ituiutaba, dentre elas ao representante do Conselho Municipal do Idoso e ao gestor municipal ligado à SEDS de Ituiutaba.

Por fim, é notada a necessidade de ampliar a discussão do tema políticas públicas, principalmente para a população idosa, uma vez que as mesmas tratam de direitos importantes que garantem que a velhice transcorra de forma digna e com mais qualidade. Também é preciso fortalecer os CRAS, uma vez que, este se constitui uma importante política pública e um local onde o idoso encontra acolhimento e prazer.

\section{CONSIDERAÇÕES FINAIS}

Esse estudo teve como objetivo geral perceber como os idosos que frequentam os CRAS instalados na cidade de Ituiutaba (MG) avaliam as políticas públicas voltadas para a população idosa. Durante a construção do referencial teórico foi possível conhecer e entender quais são essas políticas e por quais legislações as mesmas são resguardadas. Já a realização das entrevistas com os idosos que

$\begin{array}{lllll}\text { Caminhos de Geografia } & \text { Uberlândia-MG } & \text { v. 21, n. } 76 & \text { Ago/2020 } & \text { p. 208-230 Página } 227\end{array}$


frequentam os 06 (seis) CRAS instalados em Ituiutaba, permitiu conhecer a avaliação dos mesmos sobre as políticas públicas voltadas para a população idosa, bem como sua falta de conhecimento sobre parte do assunto, além de seus anseios e necessidades.

Mediante a avaliação dos idosos, foi possível analisar as políticas públicas voltadas para a população idosa materializadas pelas legislações nacionais e municipais e sua efetividade ou não. Porém, ficou claro que há uma grande dificuldade dos idosos em entender o conceito de política pública e quais são os direitos que os mesmos possuem. Direitos esses que devem ser garantidos por tais políticas.

No tocante às políticas públicas, voltadas para a população idosa, já implementadas no município de Ituiutaba, as mesmas foram apontadas tanto pelos idosos tendo como base as legislações vigentes. Porém, os idosos indicaram quais políticas públicas ainda precisam ser efetivadas no município, com base nas suas necessidades e anseios.

Dentre os entraves encontrados, pode-se citar a dificuldade em obter dados em relação ao Município, seja no que se refere à quantidade de idosos atendidos por CRAS ou até mesmo a quantificação desses idosos por bairros ou regiões. Além disso, por envolver aspectos políticos, foram encontradas algumas barreiras ou resistências na obtenção de informações por parte do grupo pesquisado ou até para a realização das entrevistas. Porém, diante da argumentação de que se trata de um tema relevante e de um trabalho que pode ajudar na melhoria dos serviços prestados pelo poder municipal, o acesso foi facilitado.

Trata-se de um tema relevante, uma vez que cuidar da população idosa é cuidar do futuro das novas gerações. E, envelhecer com qualidade e de forma digna possibilita uma velhice produtiva e saudável. Nessa perspectiva, as políticas públicas, voltadas para a população idosa, são fundamentais para que os direitos sejam efetivados, uma vez que estão garantidos por leis. Porém, é fundamental que tais políticas, além de serem implementadas, sejam divulgadas principalmente para aqueles que irão usufruí-las por direito.

A conclusão desse estudo evidenciou a necessidade do desenvolvimento de mais pesquisas que contribuam para a valorização das pessoas idosas, bem como para que as políticas públicas que garantam uma velhice com qualidade sejam efetivadas. É notório que legislações para isso não faltam, porém é preciso que os direitos garantidos legalmente aos idosos "saiam do papel" e se tornem uma realidade para aqueles que deles necessitam. É, portanto, necessário ampliar as discussões e abrir espaços para debates e informações, sejam nos órgãos que atendem os idosos, sejam nos espaços acadêmicos ou políticos.

\section{REFERÊNCIAS}

BERQUÓ, Elza; BAENINGER, Rosana. Os idosos no Brasil: considerações demográficas. Campinas: Unicamp, Núcleo de Estudos de População, 2000. 69 p. (Textos NEPO). Disponível em: http://www.nepo.unicamp.br/publicacoes/textos_nepo/textos_nepo_37.pdf. Acesso em: 13 ago. 2018.

BRASIL. Atlas do Desenvolvimento Humano no Brasil. Ituiutaba, MG.2015. Programa das Nações Unidas para o Desenvolvimento; Instituto de Pesquisa Econômica Aplicada; Fundação João Pinheiro. Disponível em: http://www.atlasbrasil.org.br/2013/pt/o_atlas/o_atlas_l. Acesso em: 30 mar. 2018.

BRASIL. Decreto $n^{\circ} 1.948$, de 03 de julho de 1996. Regulamenta a Lei $n^{\circ} 8.842$, de 4 de janeiro de 1994, que dispõe sobre a Política Nacional do Idoso, e dá outras providências. Brasília, DF: Diário Oficial da União, 04 jul. 1996. Disponível em: https://www2.camara.leg.br/legin/fed/decret/1996/decreto-1948-3-julho-1996-435785publicacaooriginal-1-pe.html. Acesso em: 21 maio 2019.

BRASIL. Decreto $n^{\circ} 3.048$, de 06 de maio de 1999. Aprova o regulamento da Previdência Social, e dá outras providências. Brasília, DF: Diário Oficial da União, 07 maio 1999. Disponível em: http://www.planalto.gov.br/ccivil_03/decreto/D3048.htm\#art3. Acesso em: 16 maio 2019.

BRASIL. Lei $n^{\circ} 3.807$, de 26 de agosto de 1960. Dispõe sobre a Lei Orgânica da Previdência Social. Brasília, SF: Diário Oficial da União, 05 set. 1960. Disponível em: http://legis.senado.gov.br/norma/545629/publicacao/15763729. Acesso em: 16 maio 2019.

BRASIL. Lei $n^{\circ}$ 8.742, de 07 de dezembro de 1993.Dispõe sobre a organização da Assistência Social e dá outras providências: Lei Orgânica da Assistência Social. Brasília, DF. Diário Oficial da União, 08 
dez. 1993. Disponível em: http://www.planalto.gov.br/ccivil_03/leis//8742.htm. Acesso em: 11 abr. 2018.

BRASIL. Lei $n^{\circ} 8.842$, de 04 de janeiro de 1994. Dispõe sobre a política nacional do idoso, cria o Conselho Nacional do Idoso e dá outras providências: Política Nacional do Idoso. Brasília, DF. Diário Oficial da União, 05 jan. 1994. Disponível em: http://www.planalto.gov.br/ccivil_03/leis/l8842.htm. Acesso em: 30 abr. 2018.

BRASIL. Lei $n^{\circ} 10.741$, de $1^{\circ}$ de outubro de 2003. Dispõe sobre o Estatuto do Idoso e dá outras providências: Estatuto do Idoso. Brasília, DF. Diário Oficial da União, 03 out. 2003. Disponível em: http://www.planalto.gov.br/ccivil_03/leis/2003//10.741.htm. Acesso em: 20 abr. 2018.

BRASIL. Lei $n^{\circ} 11.433$, de 28 de dezembro de 2006. Dispõe sobre o Dia Nacional do Idoso. Brasília, DF: Diário Oficial da União, 29 dez. 2006. Disponível em: <http://www.planalto.gov.br/ccivil_03/_Ato2004-2006/2006/Lei/L11433.htm>. Acesso em: 16 jul. 2019.

BRASIL. Ministério da Saúde. Portaria GM no 1.395, de 10 de dezembro de 1999. Aprova a Política Nacional de Saúde do Idoso e dá outras providências. Brasília, DF. Diário Oficial da União, 13 dez. 1999. Disponível em: https://www.ufrgs.br/3idade/?page_id=117. Acesso em: 21 maio 2019.

BRASIL. Ministério da Saúde. Portaria GM n 2.528, de 19 de outubro de 2006. Aprova a Política Nacional de Saúde da Pessoa Idosa. Brasília, DF. Diário Oficial da União, 20 out. 2006. Disponível em: http://bvsms.saude.gov.br/bvs/saudelegis/gm/2006/prt2528_19_10_2006.html. Acesso em: 21 maio 2019.

BRASIL. Presidência da República. Constituição da República Federativa do Brasil de 1988. Brasília: Senado, $1988 . \quad$ Disponível em: http://www.planalto.gov.br/ccivil_03/constituicao/constituicao.htm. Acesso em: 04 abr. 2018.

BRASIL. Ministério do Desenvolvimento Social. Centro de Referência de Assistência Social - CRAS. Brasília, 2015. Disponível em: http://mds.gov.br/assuntos/assistencia-social/unidades-deatendimento/cras. Acesso em: 29 out. 2018.

CRUVINEL, Tomaz Alberto Costa. Promoção da saúde e qualidade de vida nos idosos na saúde da família. Especialização - Atenção Básica em Saúde da Família, Universidade Federal de Minas Gerais, 2009.

FERNANDES, Maria Teresinha de Oliveira; SOARES, Sônia Maria. O desenvolvimento de políticas públicas de atenção ao idoso no Brasil. Revista da Escola de Enfermagem da USP, [s.I.], v. 46, n. 6 , p.1494-1502, dez. 2012. Fap UNIFESP (SciELO). https://doi.org/10.1590/S0080-62342012000600029

FONSECA, Dagoberto José. Políticas públicas e ações afirmativas. São Paulo: Selo Negro, 2009. $140 \mathrm{p}$.

IBGE. Instituto Brasileiro de Geografia e Estatística. Cidades@: Minas Gerais - Ituiutaba. 2017. Disponível em: https://cidades.ibge.gov.br/brasil/mg/ituiutaba/panorama. Acesso em: 26 mar. 2018.

IBGE. PNAD 2016: população idosa cresce 16,0\% frente a 2012 e chega a 29,6 milhões. 2017. Disponível em: https://agenciadenoticias.ibge.gov.br/agencia-noticias/2013-agencia-denoticias/releases/18263-pnad-2016-populacao-idosa-cresce-16-0-frente-a-2012-e-chega-a-29-6milhoes.html. Acesso em: 27 mar. 2018.

IBGE. Projeção da População 2018: número de habitantes do país deve parar de crescer em 2047. 2018. Disponível em: https://agenciadenoticias.ibge.gov.br/agencia-sala-de-imprensa/2013-agenciade-noticias/releases/21837-projecao-da-populacao-2018-numero-de-habitantes-do-pais-deve-pararde-crescer-em-2047. Acesso em 11 set. 2018.

ITUIUTABA. Prefeitura Municipal de Ituiutaba. Cartilha da Pessoa Idosa.Ituiutaba: PMI, s./d. 15 p.

ITUIUTABA. Lei $n^{\circ} 1.363$, de 10 de dezembro de 1970. Institui o Código de Posturas do Município de Ituiutaba e dá outras providências. Código de Posturas. Ituiutaba, MG, p. 1-133. Disponível em: http://www.ituiutaba.mg.leg.br/leis/codigos-municipais/lei-no-1363-codigo-de-posturas.docx/view. Acesso em: 05 jun. 2018.

ITUIUTABA. Lei no 3.231, de 24 de abril de 1997. Institui o Conselho Municipal de Assistência Social e dá outras providências. Ituiutaba, MG, 24 abr. 1997. Disponível em: http://www.ituiutaba.mg.leg.br/leis/lei-municipal/leis-ordinarias/ano-de-1997/lei-no-3-231-de-24-deabril-de-1997/view. Acesso em: 23 maio 2019.

$\begin{array}{lllll}\text { Caminhos de Geografia } & \text { Uberlândia-MG } & \text { v. 21, n. } 76 & \text { Ago/2020 } & \text { p. 208-230 Página } 229\end{array}$


ITUIUTABA. Lei $n^{\circ}$ 3.232, de 24 de abril de 1997. Institui o Fundo Municipal de Assistência Social, e dá outras providências. Ituiutaba, MG, 24 abr. 1997. Disponível em: http://www.ituiutaba.mg.leg.br/leis/lei-municipal/leis-ordinarias/ano-de-1998/lei-no-3-232-de-24-deabril-de-1997/view. Acesso em: 23 maio 2019.

ITUIUTABA. Lei $n^{\circ} 3.269$, de 17 de dezembro de 1997. Assegura o pagamento de meia entrada aos idosos e dá outras providências. Ituiutaba, MG, 17 dez. 1997. Disponível em: http://www.ituiutaba.mg.leg.br/leis/lei-municipal/leis-ordinarias/ano-de-1997/lei-no-3-269-de-17-dedezembro-de-1997/view. Acesso em: 29 maio 2019.

ITUIUTABA. Lei $n^{\circ} 3.606$, de 23 de março de 2003. Institui o Conselho Municipal do Idoso. Ituiutaba, MG, 23 mar. 2003. p. 1. Disponível em: http://www.ituiutaba.mg.leg.br/leis/lei-municipal/leisordinarias/ano-2003/lei-no-3-606-de-23-de-abril-de-2003/view. Acesso em: 06 maio 2019.

ITUIUTABA. Lei $n^{\circ} 3.831$, de 11 de janeiro de 2007. Concede prioridade aos cidadãos idosos, nos casos que menciona e dá outras providências. Ituiutaba, MG, 11 jan. 2007. Disponível em: http://www.ituiutaba.mg.leg.br/leis/lei-municipal/leis-ordinarias/ano-2007/lei-no-3-831-de-11-de-janeirode-2007/view. Acesso em: 29 maio 2019.

ITUIUTABA. Lei $n^{\circ} 3.907$, de 13 de dezembro de 2007. Altera a Lei $n^{\circ} 3.606$, de 23 de abril de 2003, que instituiu o Conselho Municipal de Idoso e dá outras providências. Ituiutaba, MG, 13 dez. 2007. Disponível em: http://www.ituiutaba.mg.leg.br/leis/lei-municipal/leis-ordinarias/ano-2007/lei-no-3-907de-13-de-dezembro-de-2007/view. Acesso em: 28 maio 2019.

ITUIUTABA. Lei $n^{\circ} 4.099$, de 25 de agosto de 2011. Altera a Lei $n^{\circ} 3.907$, de 13 de dezembro de 2007, que instituiu o Conselho Municipal do Idoso e dá outras providências. Ituiutaba, MG, 25 ago. 2011. Disponível em: https://static-data.com.br/pmi/upload/publicacoes/lei-n-4-099-de-25-deagosto-de-2011.pdf. Acesso em: 28 maio 2019.

ITUIUTABA. Lei $n^{\circ} 4.351$, de 23 de abril de 2015. Cria o Fundo Municipal do Idoso e dá outras providências. Ituiutaba, MG, 23 abr. 2015. Disponível em: https://staticdata.com.br/pmi/upload/publicacoes/lei-n-4-351-de-23-de-abril-de-2015.pdf. Acesso em: 26 jun. 2019.

ITUIUTABA. Lei $n^{\circ} 4.507$, de 06 de julho de 2017. Institui o Plano de Mobilidade Urbana de Ituiutaba e dá outras providências. Ituiutaba, MG, 06 jul. 2017. Disponível em: https://staticdata.com.br/pmi/upload/publicacoes/lei-n-4-507-de-06-de-julho-de-2017.pdf. Acesso em: 29 jun. 2019.

ITUIUTABA. Lei Complementar $n^{\circ} 153$, de 13 de julho de 2018. Institui a Revisão do Plano Diretor Integrado do Município de Ituiutaba, e dá outras providências. Plano Diretor. Ituiutaba, MG, p. 1-56. Disponível em: https://www.ituiutaba.mg.leg.br/leis/lei-municipal/leis-complementares/ano-de-2018/leicomplementar-no-153-de-13-de-julho-de-2018/view. Acesso em: 05 jun. 2019.

MOURA, Giselle Alves de; SOUZA, Luciana Karine de. Autoimagem, socialização, tempo livre e lazer: quatro desafios à velhice. Textos \& Contextos, Porto Alegre, v. 11, n. 1, p.172-183, jan./jul. 2012. Disponível em: http://revistaseletronicas.pucrs.br/ojs/index.php/fass/article/view/9492/8050. Acesso em: 11 set. 2018.

ONU. Organização das Nações Unidas. Declaração Universal dos Direitos Humanos (DUDH). Assembleia Geral das Nações Unidas: 1948. Disponível em: http://www.onu.org.br/img/2014/09/DUDH.pdf. Acesso em: 03 maio 2018.

SILVA, Ferlice Dantas e; SOUZA, Ana Lúcia de. Diretrizes internacionais e políticas para o idoso no Brasil: a ideologia do envelhecimento ativo. Revista de Políticas Públicas, São Luís, v. 14, n. 1, p.8594, jan. 2010. Disponível em: http://www.redalyc.org/articulo.oa?id=321127307009. Acesso em: 16 maio 2019.

WORLD HEALTH ORGANIZATION. Envelhecimento ativo: uma política de saúde. Tradução de Suzana Gontijo. Brasília: Organização Pan-americana da Saúde, 2005. 60 p. Disponível em: http://bvsms.saude.gov.br/bvs/publicacoes/envelhecimento_ativo.pdf. Acesso em: 01 jun. 2018.

Recebido em: 26/01/2020

Aceito para publicação em: 20/05/2020 